
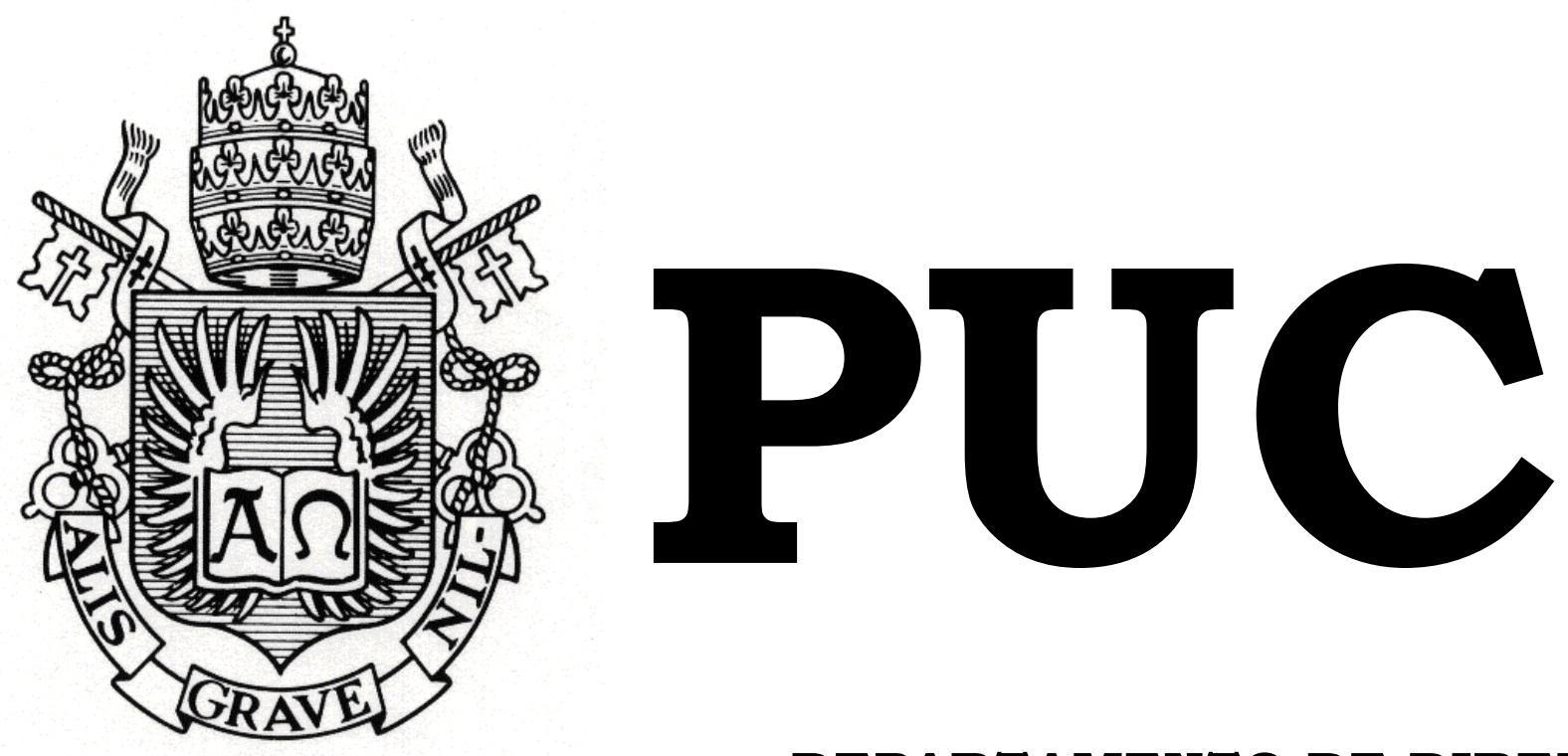

DEPARTAMENTO DE DIREITO

Lei Maria da Penha, Feminismo Negro e Criminologia Critica: Escrevivências a partir da Interseccionalidade por

MARINA DE OLIVEIRA REIS

ORIENTADOR(A): Thula Rafaela de Oliveira Pires

2018.2

PONTIFÍCIA UNIVERSIDADE CATÓLICA DO RIO DE JANEIRO RUA MARQUÊS DE SÃO VICENTE, 225 - CEP 22453-900 RIO DE JANEIRO - BRASIL 


\title{
Lei Maria da Penha, Feminismo Negro e Criminologia Crítica: Escrevivências a partir da Interseccionalidade
}

\author{
por
}

MARINA DE OLIVEIRA REIS

Departamento de Direito da Pontificia Universidade Católica do Rio de Janeiro (PUC-Rio) para a obtenção do Título de Bacharel em Direito.

Orientador(a): Thula Rafaela de Oliveira Pires 


\section{RESUMO}

Esse trabalho responde ao chamado de produção de uma nova gramática para pautar o enfrentamento da violência doméstica. Denunciando a forma essencialista que essa discussão tem sido feita até então, retomamos as disputas travadas por criminologias e feminismos hegemônicos em torno da Lei Maria da Penha. Parte-se da hipótese que ambos os campos são cegos às dinâmicas de violência doméstica perpetrada contra mulheres negras, na medida em que suas análises são norteadas pela branquitude, ou seja, a categoria "mulher" é adotada enquanto sujeito destituído de raça, classe, sexualidade, etc. Indo na contra-mão dessa tendência, apostamos nos feminismos negros e decolonial, assim como em abordagens que pautam o sistema de justiça criminal em outros termos, para chamar atenção às dinâmicas de violência que afetam mulheres negras de forma particular.

Palavras chave: Lei Maria da Penha, Violência Doméstica contra a mulher, Criminologia Crítica, Feminismo Negro, Interseccionalidade, Decolonial 


\section{SUMÁRIO}

Introdução...................................................... 4

1. Nossos passos vêm de longe: raça e gênero a partir de uma perspectiva decolonial .......................................................

1.1 Raça: Da volta em torno do Baobá à colonialidade do poder....... 16

1.2 Gênero: Da invenção da mulher Ialodês à colonialidade do gênero

2. Todas as mulheres são brancas, todos os homens são negros, mas algumas de nós temos coragem ....................................................... 23

2.1 Das muitas dimensões do não lugar ...................................... 23

2.2 Das muitas formas de resistência: Interseccionalidade e Imbricação como possibilidades de visibilização

2.2.1 Ajustando as lentes: uma leitura dos dados sobre violência contra mulheres a partir da imbricação

3. Dororidade: A Violência Doméstica e Familiar contra mulheres Negras

3.1 Os essencialismos reproduzidos pelo Direito ......................... 37

3.2 A Lei Maria da Penha 40

4. Discursos negros situando Feminismos e Criminologias ........... 46

4.1 Lendo as estruturas: Feminismo Negro ................................. 47

4.2 Lendo o sistema punitivo: Criminologia Crítica ...................... 50

4.3 De que vítima estamos falando? O encontro do direito penal com os estereótipos de gênero

Conclusão

60

Referências 


\section{INTRODUÇÃO}

O presente trabalho teve como ponto de partida a tensão entre feministas e criminólogos críticos nos debates em torno da Lei Maria da Penha. Desde a promulgação da lei, os dois campos apresentam análises que parecem inconciliáveis: de um lado, o movimento feminista, em geral, demanda um maior rigor no trato das múltiplas formas de violência contra a mulher, inclusive com maior intervenção penal e, de outro, criminólogos se mostram resistentes às discussões de gênero, desconsiderando a importância de mobilizar essa lente para a leitura dos discursos e práticas punitivas. Porém, como mulher negra, muito me chamou atenção os termos nos quais a disputa se dá: ambos os campos adotam análises que centralizam a branquitude enquanto parâmetro, o que ocasiona um completo silêncio sobre violências perpetradas contra mulheres negras, mesmo quando as estatísticas denunciam o fato de que são mulheres negras as maiores vítimas de estupro e mortes violentas no país. Para onde vão esses silêncios? O que eles significam? Que estruturas pretendem manter?

Nesse sentido, o que move a minha escrita é o incômodo. O incômodo do vilipêndio dos corpos e dos silêncios produzidos. $\mathrm{O}$ incômodo do abafamento das vozes e da consequente naturalização do extermínio. O incômodo do apagamento e de uma dor que não registra. Enfím, o incômodo da invisibilidade - que é a morte em vida, como bem colocado por Azoilda Loretto da Trindade. Aqui, porém, o incômodo é para além do negro-tema1: ao contrário do que pretendem alguns/algumas "aliados/as",

\footnotetext{
${ }^{1}$ Termo utilizado na obra de Guerreiro Ramos (1955), que contrasta com a categoria "negro-vida". Segundo ele (p. 215), "há o tema do negro e há a vida do negro. Como tema, o negro tem sido, entre nós, objeto de escalpelação perpetrada por literatos e pelos chamados "antropólogos" e "sociólogos". Como vida ou realidade efetiva, o negro vem assumindo o seu destino, vem se fazendo a si próprio, segundo lhe têm permitido as condições particulares da sociedade brasileira. Mas uma coisa é o negro-tema; outra, o negro-vida. O negro-tema é uma coisa examinada, olhada, vista, ora como ser mumificado, ora como ser curioso, ou de qualquer modo como um risco, um traço da realidade nacional que chama a atenção. O negro-vida é, entretanto, algo que não se deixa imobilizar; é despistador, profético, multiforme, do qual, na verdade, não se pode dar versão definitiva, pois é hoje o que não era ontem e será amanhã o que não é hoje”.
} 
não se trata de pintar de preto a vasta produção acadêmica sobre violência de gênero. Se algumas premissas não forem, de fato, entendidas e a discussão não partir de um lugar que reconheça o racismo como estruturador de subjetividades e relações sociais e institucionais, nenhuma análise conseguirá dar conta das violências perpetradas contra de mulheres negras. Em outras palavras, mobilizar a lente da raça para refletir sobre violência doméstica, no mínimo, muda tudo.

Assumindo essa empreitada, me apropriei dos embates dos feminismos e criminologias, colocando o foco nas tensões e lendo-as a partir através de aportes construídos por mulheres negras. Partir de conceitos e teorias formulados, principalmente, por mulheres negras é um imperativo para um trabalho como este. Entendendo que muitas das hierarquizações são produzidas e reproduzidas pelo sequestro da palavra, a bibliografia aqui adotada se traduz em um esforço de contribuir para uma insurgência afrocentrada que dê conta das dimensões dos muitos epistemicídios e da hegemonia das páginas brancas. Além disso, destacamos a potência inscrita nessas análises, capazes não só de denunciar as naturalizações e essencialismos constantemente reproduzidas por discursos feministas e criminológicos hegemônicos, mas também capazes de confrontar e intervir na realidade que herdamos.

Portanto, não é qualquer criminologia crítica que chamo para a conversa. Como bem diagnostica Thula Pires (2017), o campo dos estudos criminológicos está marcado pelo pacto narcísico, que racializa a questão nos termos do "negro-tema", sem nem ao menos se interpelar. Assim, dada a não compreensão e a não adoção dos marcos teóricos sobre relações raciais no Brasil, o processo histórico de distribuição de ônus e bônus raciais a determinados corpos resta invisível. E, estando invisível, a própria engrenagem da punição não é entendida, fazendo com que, quando muito, uma abordagem "colorida" seja dada em uma linha ou duas sobre a seletividade penal ou a cor do cárcere, sem promoção de um debate sério sobre a questão racial e o sistema penal. Em outras palavras, "a 
criminologia jamais se interessou em investigar o racismo como parte da estrutura e da própria lógica de funcionamento do sistema" e, por isso, se limita a retomar a base escravocrata do sistema penal ou produzir uma reflexão tímida sobre os clientes preferenciais do sistema (FREITAS, 2016). Assim, ainda que esse campo se coloque como "crítico", na verdade, não é crítico o suficiente para evidenciar como gênero, classe e sexualidade operam de maneira racializada. Uma análise nesses termos não nos interessa, pois, para nós, "não basta dizer que há seletividade racial e de gênero no modo de atuação dos órgãos de justiça criminal (PIRES, 2017, p. 542). Isso a gente já sabe. Isso é secularmente experimentado por corpos muito bem definidos - os nossos.

Também não é qualquer perspectiva feminista que vou abordar. Adoto os aportes do feminismo decolonial e do feminismo negro por acreditar em suas potencialidades de desvendar as estruturas de poder e dimensões de dominação que vão muito além de aspectos econômicos ou políticos. Obviamente, nenhuma teoria consegue dar conta das complexidades trazidas pelas vivências dos sujeitos, mas ambas, se aliadas, conseguem revelar muito da nossa experiência enquanto mulheres negras em Abya Yala².

Primeiramente, o feminismo negro há tempos denuncia que as possibilidades de ser, viver e estar no mundo não são experimentadas por todo o corpo social da mesma forma. Feministas negras foram as primeiras a atentar ao fato de que variados vetores de opressão pode estar articulados, formando um modo de subordinação próprio. Assim, a partir da politização de suas experiências, desenvolvem uma análise capaz de denunciar as diversos padronizações e hierarquizações presentes na sociedade. Aproximo-me desta perspectiva teórica na medida em que ela me ajuda a pensar as dinâmicas de violência doméstica contra a mulher não apenas

\footnotetext{
${ }^{2}$ Abya Yala, na língua do povo Kuna (povo que habita o território correspondente ao Panamá e a Colômbia), significa Terra Madura, Terra Viva ou Terra em florescimento. É o termo utilizado para denominar o continente que os colonizadores espanhóis chamaram de "América". Disponível em <https://bit.ly/2Q8X6uO>
} 
como um fenômeno interpessoal advindo de uma estrutura patriarcal, mas como algo que está diretamente relacionada com as estruturas de poder da sociedade e, em última instância, diretamente relacionada com raça, classe, violência governamental e poder (DAVIS, 1985, p. 10).

A ideia de que variados eixos de opressão e violência se articulam, formando uma dinâmica de subordinação específica, vem sendo trabalhada há muito tempo por diversas mulheres negras em diáspora, como será demonstrado nos próximos capítulos. Porém, enquanto marco teórico conceitual próprio, essa construção se formata nos anos 90, sendo cunhado o termo interseccionalidade. A crítica colocada pelo feminismo decolonial, porém, é que ainda que a partir da lente da interseccionalidade seja possível desvendar as diversas camadas que atravessam as estruturas de poder da nossa sociedade, muita coisa ainda fica escondida. $\mathrm{Na}$ agenda da interseccionalidade, como conceito cunhado por intelectuais negras norteamericanas, não há lugar explícito, por exemplo, para tratar de colonialidade e imperialismo.

Dessa forma, como defendido por Ochy Curiel, o conceito de imbricação vem de um pensamento decolonial, que pretende pensar a realidade das mulheres negras atravessando a discussão do imperialismo e colonialidade. O feminismo decolonial aprende com o feminismo interseccional e nos oferece uma análise que centraliza as marcas da colonialidade tanto na constituição da subjetividade, como na dimensão epistemológica e práticas de poder. Especialmente se estamos falando sobre violência contra mulheres negras em Abya Yala, essa perspectiva pode ser muito rica, pois é possível atentar aos vínculos entre as diversas formas de violência sofridas por esse grupos com o legado colonialista (MONJE, 2017). Ao adotar essa perspectiva, é possível entender a violência como um fenômeno multidimensional e a análise dessa problemática parte de um lugar distinto, entendendo o passado como uma herança que construiu relações coloniais (MONJE, 2017). 
Tais escolhas me abriram possibilidades e me levaram a outros lugares. Através destes aportes, pretendo produzir uma reflexão, ainda que tímida, capaz de ir além da dicotomia "a Lei Maria da Penha é boa" ou "a Lei Maria da Penha é ruim". A referida lei não pode continuar sendo analisada só por uma ótica de gênero, sob pena de ser aplicável e eficaz a uma parte limitada da população: mulheres brancas, de classe média e heterossexuais. Assim, devemos debater em que medida os dispositivos legais vigentes contemplam mulheres negras. Será que eles conseguem acessar e dar conta de nossas especificidades? Ou são cegos às dinâmicas de racismo e classismo que muitas mulheres brasileiras sofrem, além do sexismo?

Nada está pacificado e nem há resposta pronta.

Importante colocar, logo nessas páginas iniciais, que escrevo assumindo a mesma postura de Donna Haraway (2009), ou seja, entendo que os saberes são sempre localizados. Ainda que a academia se apresente como um espaço onde é possível esconder-se sob o manto da neutralidade e imparcialidade, a realidade nos mostra que, de fato, o que ocorre é o exato oposto daquilo que se declara. Tal postura, na verdade, se traduz em uma estratégia eficaz de ter uma microvisão totalmente parcial que funciona para invisibilizar vozes historicamente subalternizadas. Reconheço, portanto, que todos nós falamos de um lugar.

Sendo assim, me sinto impelida em apresentar ao leitor/a de onde este trabalho fala, de quem fala, como fala. Essa escrita parte de uma mulher negra periférica, nascida e criada em Campo Grande, subúrbio do Rio de Janeiro. Estes dados não só me constroem como pessoa, mas é a partir deste lugar que eu vejo e interpreto o mundo. Eu desejo e assumo com todas as consequências que isto pode gerar -, que esta seja a perspectiva das reflexões aqui apresentadas. Por ter crescido em uma área da cidade notoriamente conhecida por ser dominada por milícias, vivi parte da minha vida testemunhando a falência do Estado. Sei, de perto, como é ter o Estado não como protetor de garantias, mas como o principal violador 
de direitos. Com isso, se torna impossível ignorar o papel do sistema penal, que não cumpre sua promessa de proteger, já que ele só amedronta. Em última instância, o que eu quero entender é como estas perspectivas periféricas podem mudar o modo através do qual pensamos e combatemos a violência doméstica.

Para mim, essa monografia representa muito mais do que o preenchimento de uma formalidade necessária para a graduação. De certa forma, ela representa o nascimento prematuro de inquietações que venho acumulando desde 2015, momento em que comecei a dedicar meus estudos e militância para questões relacionadas ao cruzamento, muitas vezes fatal, entre raça, gênero e controle penal. O parto foi prematuro porque não achava que estava pronta para enfrentar um assunto tão denso e doloroso e nascer antes do tempo sempre tem um preço, especialmente se a luz é dada durante um ano como esse. Por isso, acho importante mencionar que mais do que uma disputa acadêmica, esse trabalho pretende servir como um grito de existência contra uma dinâmica genocida - movimentada tanto pelo Estado como por relações interpessoais - que quer ver nossos corpos sucumbirem. Se temos uma história que a história não conta, um avesso do mesmo lugar, chegou a vez de ouvir as Marias, Mahins, Marielles, malês ${ }^{3}$. Se eles não suportam nossa luta secular por perseverar na existência, juntando os cacos, seguimos nas trincheiras da resistência porque, para a gente, luto é verbo. Lutemos. Ainda que a cada 23 minutos... A cada 23 minutos. 1 a cada 23 .

Além de dialogar com nossas dororidades ${ }^{4}$ enquanto povo, esse trabalho também nasce de uma dor particular. Nas linhas e páginas a seguir, há uma dimensão pessoal. Se a violência doméstica é uma constante na vida das mulheres, na minha também não é exceção. Se constantemente denunciamos que o lar pode ser um dos lugares mais perigosos para

\footnotetext{
${ }^{3}$ Frase retirada do Samba-Enredo da Mangueira de 2019

${ }^{4}$ Para o conceito de Dororidade, ver PIEDADE, Vilma (2017)
} 
mulheres, assim também o foi para mim. Escrevo, também, para expurgar a dor. Como o próprio título evidencia, aqui estão minhas escrevivências.

O trabalho é estruturado a partir de obras que visibilizam e politizam as pautas de mulheres negras e, assim, cada um dos 4 capítulos recebe o nome de um dos livros. Começamos dialogando com "O livro da saúde das mulheres negras: nossos passos vêm de longe", num esforço de pautar raça e gênero a partir da decolonialidade. Nos localizando a partir da amefricanidade, tomamos os conceitos de colonialidade do poder e colonialidade de gênero para repensar esquemas de subordinação pactuados e constantemente repactuados na atualidade.

No segundo capítulo, trazemos a antologia "All the Women are White, all the Blacks are Men, but some of us are Brave: Black Women's Studies" por seu pioneirismo em marcar a institucionalização do campo de estudos sobre mulheres negras nos Estados Unidos. Aqui, parece especialmente interessante dialogar com o título da obra, e é a partir dessa noção que exploramos ainda mais como a tendência de tratar raça e gênero como categorias mutuamente excludentes desenha um espaço de não lugar para mulheres negras. Contra essa tendência, apresentamos a interseccionalidade e a imbricação enquanto teorias e práticas de resistência, na medida em que denunciam a invisibilidade da lente hegemônica, repautando a discussão.

Com esse caminho percorrido, discutimos a violência doméstica contra mulheres negras a partir do conceito de dororidade. Assim, capítulo 3 mobiliza a lente da raça para analisar o contexto de violência doméstica. Além disso, discutimos a tendência das legislações em assumirem uma abordagem essencialista e, por fim, introduzimos a Lei Maria da Penha (Lei 11.340/06), discorrendo sobre seu contexto, objetivos e consequências geradas.

Por fim, colocamos o feminismo e a criminologia crítica no centro da roda para analisar a Lei Maria da Penha, a partir de "Discursos Negros Legislação Penal, Política Criminal e Racismo", livro fundamental para a 
execução desse trabalho. Partindo das provocações colocadas pelo artigo de Ana Flauzina, chamamos atenção aos aspectos estruturais, discutindo o que significa uma apropriação punitivista da lei. 


\title{
Capítulo 1. Nossos passos vêm de longe: raça e gênero a partir de uma perspectiva decolonial
}

\begin{abstract}
Aqueles homens ali dizem que as mulheres precisam de ajuda para subir em carruagens, e devem ser carregadas para atravessar valas, e que merecem o melhor lugar onde quer que estejam. Ninguém jamais me ajudou a subir em carruagens, ou a saltar sobre poças de lama, e nunca me ofereceram melhor lugar algum! E não sou uma mulher? Olhem para mim? Olhem para meus braços! Eu arei e plantei, e juntei a colheita nos celeiros, e homem algum poderia estar à minha frente. E não sou uma mulher? Eu poderia trabalhar tanto e comer tanto quanto qualquer homem - desde que eu tivesse oportunidade para isso - e suportar o açoite também! E não sou uma mulher? Eu pari treze filhos e vi a maioria deles ser vendida para a escravidão, e quando eu clamei com a minha dor de mãe, ninguém a não ser Jesus me ouviu! E não sou uma mulher?
\end{abstract}

Sojourner Truth

O grito por existência acima é a didática a partir de um soco no estômago. Ao centralizar processos históricos de existência e resistência, de forma simples e direta, denuncia aquilo que muitos "humanistas" ainda não entenderam: a interrelação entre racismo e seximo faz com que os corpos atravessados por estas dinâmicas não sejam lidos como sujeitos que possam ter sua humanidade plenamente reconhecida. Nos é reservado a invisibilidade, o não lugar, o não ser, sendo.

À nossos corpos, o mito da fragilidade feminina não se aplica. Nunca pudemos ser apenas "do lar". Historicamente, nossa identidade era de objeto e trabalhamos por séculos como escravas da lavoura, da casa grande, de ganho, como vendedoras, quituteiras, prostitutas... Não somos a musa idolatrada dos poetas, já que o ideal da beleza é diretamente associado à brancura - e nós... ah, nós temos um "defeito de cor" (CARNEIRO, 2003). Nos é negado o direito de sentir dor, tanto que até na sala de parto os estereótipos racistas operam e fazem com que sejamos o grupo racial que 
menos recebe anestesia ${ }^{5}$. Se saímos vivas da maternidade, ainda temos que reivindicar o direito de conseguir criar nossos filhos e vê-los vivos já que a resultante desta política de segurança de caráter genocida ${ }^{6}$ é cristalizada na imagem da mãe negra curvada, velando os corpos de seus filhos/as.

Nos é negado, a um só tempo, tanto a possibilidade de ser mulher como a possibilidade de acessarmos todos os efeitos concretos e simbólicos que o uso do termo "humano" acarreta. Indo neste sentido, podemos discorrer infinitamente outros exemplos concretos da vida real que indicam os modos pelos quais racismo e sexismo operam de forma a projetar para as mulheres negras uma situação de desigualdade desproporcional, que vai desde o fato de ocuparem base da pirâmide social até terem lugar marcado em toda e qualquer estatística criminal. Entretanto, como este trabalho pretende, especificamente, refletir sobre os processos de violência contra a mulher e a resposta dada no campo legal, quero destacar inicialmente um ponto que pode ser o fio condutor da nossa análise: nos é negado, inclusive, o direito de sermos vítimas. Isso porque o sistema de justiça e o direito penal funcionam a partir de certos códigos e, como as mulheres negras estão tanto fora da zona do ser como longe daquilo que se pactuou do que é “ser" mulher, a própria possibilidade de acessar o sistema e reivindicar o lugar de vítima esbarra neste sistema de opressão (FLAUZINA, 2015). Voltaremos a esta reflexão em momento oportuno.

Por agora, é necessário reforçar o fato de que, ao refletir sobre a temática da violência doméstica contra mulheres negras, a narrativa deve começar de outro lugar, trazendo outras vozes, outras cores, outros conceitos e teorias. Esse processo de reflexão deve balizado por um

\footnotetext{
${ }^{5}$ Segundo dados levantados pela Fundação Oswaldo Cruz durante os 1999-2001, mulheres negras recebem menos anestesia no parto normal na rede pública de saúde em comparação a mulheres brancas. Ver LEAL, M.C.; GAMA, S.G.N.; CUNHA, C.B. Desigualdades raciais, sóciodemográficas e na assistência ao pré-natal e ao parto, 1999- 2001. Revista de Saúde Pública. São Paulo, v. 39, n. 1, 2005.

${ }^{6}$ Sobre o genocídio contra o povo negro, ver: FLAUZINA, 2008; VARGAS, 2010.
} 
comprometido genuíno com a crítica dos processos históricos e sociais que nos trouxeram até aqui e que nos afetam de forma singular. E se é para começar desse outro outro lugar, comecemos.

Iniciamos a partir da necessidade de situar histórica e socialmente a experiência das mulheres negras brasileiras. Logo de cara, recorro a Lélia Gonzalez, pegando emprestado o conceito de "amefricanidade", na medida em que, a partir dele, conseguimos inverter o centramento, colocando na agência o lugar de destaque. Em uma proposta que disputa a afrocentricidade $^{7}$ de dentro, a autora pensa a experiência latino americana a partir da diáspora africana, entendendo nossa constituição negra fora do continente africano.

Assim, somos Améfrica na medida em que somos constituídos e influenciados por formas de ação política e culturas africanas e indígenas. Por outro lado, somos ladinos porque somos fruto de um processo violento de resistência, redefinição e ressignificação. Não há "latinidade" no Novo Mundo, pois o ladino se apropria, se reinventa e interfere na realidade a partir destas influências, que são invisibilizadas pela narrativa oficial.

Aquilo que nos define com amefricanos têm relação direta com a maneira pela qual resistimos a formas de opressão/dominação, como sexismo, imperialismo, colonialismo, racismo. Sendo assim, o olhar amefricano permite um olhar da realidade de resistência a estas formas de dominação, que nos dão análises potentes no sentido de desfazer as hierarquias produzidas.

A pertença territorial, porém, não é suficiente para produzir essa crítica potente às subordinações. Como Ochy Curiel (2014) evidencia, nossa região é formada por uma massa de intelectuais e ativistas que, apesar da herança colonial, não adequam suas lentes para ver a realidade em termos amefricanos e, por isso, seguem os cânones estabelecidos pela academia para continuar colonizados/as. Por essa razão, ela defende que, justamente por conta da nossa herança, qualquer estudioso que pretenda

\footnotetext{
${ }^{7}$ Sobre o conceito de Afrocentricidade, ver ASANTE, 2009
} 
refletir sobre estruturas e relações sociais devem considerar algumas categorias, tais como raça, gênero, sexualidade, como centrais para suas propostas investigativas.

Como o conceito de amefricanidade nos situa, tanto no nível espacial, histórico e político, é a partir desta noção que vamos falar de raça e gênero, que são categorias criadas na modernidade dada a necessidade de hierarquizar os sujeitos coloniais. Neste primeiro capítulo, proponho uma reflexão sobre raça e gênero como forma de abrir o debate. De início, apresentarei as categorias por separado, pontuando sua genealogia justamente para identificar como, desde o princípio, elas estão intimamente relacionadas.

É necessário compreender que o brutal processo de colonização das Américas criou um sistema de hierarquias pautados para genderizar e racializar o sujeito colonial. A invenção de sistemas binários que estratificam seres humanos e, dentre outras coisas, definem graus de humanidade e papéis sociais (brancos x não brancos; homens x mulheres; ocidentais $\mathrm{x}$ orientais) são estratégias de dominação, fragmentação e tentativa de aniquilação de formas de resistência das sociedades coloniais. De tão bem sucedida, essa fragmentação nos impacta até hoje, na medida em que, por exemplo, constantemente discutimos as possibilidades de solidariedade dentro das lutas antirracista e antisexista.

Além de entender como racismo, patriarcado, capitalismo e colonialismo são indissociáveis, sendo parte do mesmo "pacote" de dominação das Américas/África, quero evidenciar as permanências. Este confabulação da modernidade, é tão bem sucedida nos termos em que foi projetada, que se perpetua no tempo e, assim, as suas hierarquias produzidas conseguem ser mais duradouras que o próprio colonialismo. Tais elementos são reconfigurados na atualidade conjuntamente e recaem, especialmente sobre mulheres negras, como um bloco monolítico de subordinação, às vezes pesado demais (WERNECK, 2005, p. 2). 


\subsection{Raça: Da volta em torno do Baobá à colonialidade do poder}

Conta-se que, antes de embarcarem nos navios negreiros, os africanos capturados em suas terras eram obrigados a dar inúmeras voltas em torno da árvore sagrada, em um ato simbólico que sinalizava que, a partir daquele momento, todas as suas raízes deveriam ser esquecidas. Esta árvore sagrada era o Baobá, que ficou conhecida como "árvore do esquecimento", já que simbolizava a perda da memória e da subjetividade do africano escravizado. Mais do que denunciar a brutalidade do processo colonial, este relato também fornece elementos para entendermos o conceito de colonialidade, mais especificamente, a colonialidade do poder.

Estabeleço como premissa o entendimento de que nenhuma categoria em ciências humanas nascem da imanência e muito menos são ahistóricas. Ao contrário, possuem uma origem história claramente derminável e são desenvolvidas como ferramentas de forma a operacionalizar o pensamento. Algumas categorias, porém, estão tão cimentadas no nosso imaginário que, às vezes, temos dificuldade em reconhecer que são construções sociais e não um dado da natureza. Raça, por exemplo, é uma delas. A perda da identidade e o posterior rebatismo a qual os africanos estavam submetidos englobava não apenas a inscrição em uma nova identidade cristã-ocidental, mas também a inscrição em uma categoria racial.

Neste sentido, o sociólogo peruano Aníbal Quijano (2005) descreve como "colonialidade do poder" a emergência de um novo padrão de poder mundial, que se deu a partir da imbricação dos processos de colonização da América e amadurecimento do capitalismo moderno. Este padrão de poder tem como eixo fundamental a classificação das pessoas em torno da ideia de raça e, apesar de ter uma origem colonial, foi mais duradouro e estável que o próprio projeto colonial.

O autor, de forma persuasiva, aponta para o fato de que o conceito de raça não existia antes da América. Na verdade, sua constituição é produto 
da necessidade de justificar as relações de dominação, pois o colonialismo exigia a existência um elemento que instituísse hierarquias, lugares e papeis sociais. Categorizar a humanidade em termos raciais foi um exercício de poder utilizado pelos países imperialistas europeus para justificar sua barbárie. Somente pela diminuição de todas as formas de ser, fazer e existir do outro é que os colonizadores encontraram um facilitador discursivo para normalizar a colonização.

Desta forma, raça constitui uma dita "natural" superioridade de um grupo em relação a outros, reconceituando a humanidade. Nestes termos, racializar o outro não era, apenas, diferenciá-lo de si mesmo, mas hierarquizá-lo. Povos inteiros tem sua identidade completamente apagadas e subalternizadas: astecas, maias, chimus, aimarás, incas, chibchas, por exemplo, não são outra coisa além de "índios"; achantes, iorubás, zulus, congos e bacongos não são nada mais do que "negros" (QUIJANO, 2005, p. 127).

Em outras palavras, tudo acontecia em uma via de mão dupla: ao racializar os povos africanos, os europeus também se diferenciavam ("eles são negros e eu sou branco") e, ao mesmo tempo, estabeleciam uma hierarquização hierárquica ("sou branco, portanto, superior” x "ele é negro, portanto, inferior"). Assim, de um lado, temos povos selvagens, bárbaros, sem cultura e sem história. De outro, povos mais desenvolvidos, iluminados, dotados da missão natural de levar civilização para a zona do não-ser ${ }^{8}$.

Estamos falando de um contexto de emergência do capitalismo, que encontrou condições favoráveis para se desenvolver a partir da exploração de certos corpos e do verdadeiro saque das Américas e da África (GALEANO, 2010). Com a posterior necessidade de expansão do capital, além do continente europeu, foi necessário contar com um exército de

\footnotetext{
8 Aqui, utilizamos categorias trabalhadas por Frantz Fanon (2008, p. 26). O autor utiliza o termo "zona do não ser" para caracterizar a região árida e estéril ocupada pelo negro, a partir do não reconhecimento de sua humanidade. Por outro lado, a "zona do ser" é aquela que caracteriza a posição ocupada por grupos raciais privilegiados na hierarquia social.
} 
trabalhadores que, historicamente, estão racialmente organizados nos termos do colonialismo e imperialismo. Assim, conquistados e conquistadores foram categorizadas nestes termos e depois tal classificação foi exportada para o mundo todo, na medida em que o capitalismo europeu avançava para outras parte do globo. Ou seja, a ideia de raça "inventou" em, um só tempo, as populações africanas, indígenas, muçulmanas e judias (GROSFOGUEL, 2016, p. 18) e não só novas identidades sociais surgem (índios, negros, mestiços), como outras são redefinidas (português, europeu...,) já que antes o que designava apenas espaço geográfico deveriam passar a adquirir conotações raciais (QUIJANO, 2005, p. 117).

A ideia de raça, em termos biológicos, foi refutada pela ciência há muito tempo, não tendo mais utilidade na atualidade. Nesse sentido, Ochy Curiel se questiona:

"Tendo sido demonstrado que as raças não existem como categorias da
classificação humana, mas como construções imaginárias, como uma ideia, como
significantes que contêm uma intenção política de justificar desigualdades
sociais, políticas e culturais, deveríamos dispensar o uso do termo "raça"? O que
significa renunciar uma categoria?" (CURIEL, 2014, p. 15 - tradução nossa)

Isis Conceição (2017) parece apontar um caminho. Apesar de ser uma categoria historicamente imposta e esconder uma relação de poder e dominação, se torna importante no sentido de organizar a luta antirracista:

\footnotetext{
"Raça, assim, apresenta-se como única categoria possível para pessoas cujas identidades têm que ser construídas sobre identidades socialmente forjadas, bem como é única categoria possível de auto-identificação, em face das categorias impostas pelos opressores, enquanto existirem grupos identificados por marcadores ligados à ideia de raça esse conceito sociologicamente presente tem que ser encarado como realidade a fim de viabilizar uma intervenção anti-racista" (CONCEIÇÃO, 2017, p. 2)
}

Não tem sentido pensar raça sem dar conta do racismo, na medida em que este é estrutural e estruturante em várias sentidos, estando presente 
desde a moderna formação dos Estados-Nação ${ }^{9}$ até na configuração das relações interpessoais. No Brasil, apesar do racismo ser o "amparo ideológico em que o país se apoiou e se apoia para se fazer viável" (FLAUZINA, 2006), há uma dificuldade em trabalhar neste termos na medida em ele se blinda através do mito da democracia racial.

Sendo a "neurose cerebral da sociedade brasileira" (GONZALEZ, 1984), o racismo tupiniquim é extremamente sofisticado e, assim como foi feito no tempo da escravidão, produz violências de ordem genocida a partir de um tom de "naturalidade". Se esse é o caso, devemos romper com esse mito de relações raciais harmônicas, empreendendo uma análise que reflita sobre a colonialidade do poder enquanto política articuladora das categorias de raça e gênero. Desta forma, ficará visível que o racismo organiza e ressignifica tanto a esfera pública como também a esfera privada. E é por isso que aqui insistimos em adotar a lente da raça para entender a reconfiguração das relações interpessoais e domésticas.

\subsection{Gênero: Da invenção da mulher lalodês à colonialidade do gênero}

Jurema Werneck (2005, p. 7) nos apresenta a história das ialodês, uma herança preservada pela tradição oral nas comunidades de Candomblé Ketu no Brasil. Conta-se que uma mulher trabalhadora e determinada de nome Oxum procurou ajuda dos orixás, através dos búzios, para superar dificuldades que enfrentava. Os búzios indicaram que ela deveria oferecer uma oferenda a Orixalá, o rei. Chegando ao palácio, a mulher começa a maldizer o rei, acusando-o de ser injusto, que, acuado, tenta calar a mulher com o oferecimento de presentes. Ao receber os presentes, Oxum renova as maldições, fazendo com que novos presentes lhe fossem entregues. Novos presentes são entregues e Oxum continua com seus maldizeres... até que tal processo se torna um ciclo vicioso e, ao final, por repetir este processo

\footnotetext{
${ }^{9}$ Neste sentido, ver: PAIXÃO, M. A lenda da modernidade encantada: por uma crítica ao pensamento social brasileiro sobre relações raciais e projeto de Estado Nação. Rio de Janeiro: CRV, 2014.
} 
tantas e tantas vezes, sempre exigindo novos presentes, a mulher torna-se dona de toda a riqueza.

Em uma narrativa que fala de dificuldades, resistência, organização e liderança estratégica de mulheres, ao mesmo tempo em que questiona o poder masculino, centralizo a figura das ialodês nessa seção pela sua potência em traçar uma outra ideia de mulher, que contrasta totalmente àquele ideal cunhado pela modernidade. Aqui, diferentemente do que observamos hoje, a existência de um padrão de exercício de poder pressupõe a participação das mulheres nos espaço público. Tal construção vai ao encontro de uma extensa literatura que indica que o lugar social das mulheres nas sociedades africanas e nativas das Américas ${ }^{10}$ era totalmente diferente daquele que conhecemos hoje. Para entender esta mudança, retomo o trabalho de Maria Lugones (2008), que descreve como a colonização foi responsável não só pela racialização do sujeito colonial, mas pela introdução de ideias de gênero onde antes não existia nestes termos.

A intelectual nigeriana Oyeronke Oyewumi (1997) demonstra que, historicamente, nas sociedades iorubás, gênero não foi um importante fator de organização social. Inicialmente buscando respostas através da análise da linguagem, ela identifica que língua iorubá não é marcada por palavras que denotam a divisão de gênero e, além, as próprias instituições sociais não possuem tais distinções. Levando em conta o trabalho de Oyewumi e de várias outras antropólogas africanas e latino-americanas, Maria Lugones argumenta que a categoria gênero é uma categoria violenta da colonialidade. Ao repensar o conceito de "colonialidade do poder", a autora nos convida e pensar a cartografia do poder global a partir do que se chama do sistema moderno/colonial de gênero (MONJE, 2017). Entender o

\footnotetext{
${ }^{10}$ Neste contexto, ao me referir sobre "sociedades africanas" e "nativas" não pretendo de forma alguma essencializar nem generalizar as experiência em África e nas Américas. Por não ser africana do continente, mas amefricana, entendo não ser possível afirmar categoricamente que todas as mulheres das sociedades africanas compartilham desse lugar social. Nesse sentido, me limito a afirmar e a mostrar as literaturas que vão nesse sentido.
} 
gênero nos tempos pré coloniais é importante para determinar a natureza das mudanças sociais impostas pelo processo colonial moderno eurocêntrico capitalista.

A proposta de Quijano sobre “colonialidade do poder” é interessante para historicizarmos a categorização racial, porém, sua abordagem não é suficiente para demonstrar que a emergência da categoria "gênero" também afeta diretamente as relações interpessoais e sociais e a economia, dentre outros (LUGONES, 2008). Na medida em que o autor não trabalha diretamente como a construção de gênero está inserido dentro da colonialidade do poder, não fica suficientemente explícito em seu trabalho como uma forma binária em relação ao gênero e sexualidade também produz a sujeição dos sujeitos a todos os domínios da existência. Neste sentido, Lugones se apropria da potencialidade inscrita no conceito de colonialidade do poder e desenvolve um aporte teórico que chama atenção à colonialidade do gênero. Com uma crítica construtiva, o primeiro ponto que ela chama atenção no trabalho de Quijano é o erro em supor que todas as sociedades se estruturam em torno da ideia de gênero e sexualidade (MENDOZA, 2010).

A história das Ialodês também traz outros desdobramentos. A partir dela, é possível pensar como a interferência colonial significou para as mulheres africanas, em nível individual e coletivo, o rompimento com estes padrões ancestrais de exercício de poder, tanto em aspectos políticos como a relação com o sagrado (WERNECK, 2005). Em outras palavras, como diz Breny Mendoza (2010, p. 23), "nos processos de colonização, as mulheres do mundo colonizados não só foram racializadas, mas, ao mesmo tempo, foram inventadas como "mulheres" de acordo com os códigos e princípios discriminatórios de gênero ocidental". Isso significa que, para as mulheres negras, a luta contra o patriarcado veio interligada à luta racial, pois colonialismo significou, a um só tempo, a categorização a hierarquização de gênero e de raça, que não só minam as possibilidades ancestrais de participar da esfera pública como também destituem a própria humanidade. 


\section{Capítulo 2. Todas as mulheres são brancas, todos os homens são negros, mas algumas de nós temos coragem ${ }^{11}$}

\subsection{Das muitas dimensões do não lugar}

No intuito de compreender como a construção que discutimos no capítulo anterior impacta mulheres negras na atualidade, resgato a contribuição da socióloga norte americana Patricia Hill Collins (1990), na medida em que sua análise "chama atenção para a relação entre relações discursivas e condições materiais na produção e reprodução da dominação de gênero, raça e classe" (CALDWELL, 2000). Ao pensar o lugar das mulheres negras a partir da categoria de imagens controladoras, a autora sustenta que certas imagens "são projetadas para fazer com que racismo, sexismo e pobreza parecerem naturais, normais, como uma parte inevitável de vida cotidiana" (COLLINS, 1990, p. 68). Segundo a autora, o modus operandi dessas imagens se dá pela criação de uma série de estereótipos sobre determinado grupo, fomentando representações negativas que "objetificam e desumanizam esses sujeitos, ao mesmo tempo em que servem para obscurecer e naturalizar práticas históricas e contemporâneas de dominação racial e de gênero" (CALDWELL, 2000). Estereótipos estes que foram pactuados e são constantemente atualizados desde o período colonial e propiciam a descarga de altas doses de violência sobre corpos negros.

Neste sentido, a imagem das mulheres negras é historicamente construída a partir da objetificação, sexualização e negação de seu papel enquanto sujeito político, desde o período colonial. Desta forma, a maioria das imagens controladoras a nós direcionadas é forjada como resultante da

\footnotetext{
${ }^{11}$ Ver: AKASHA, G. T. H.; SCOTT, P. B.; SMITH, B. All the Women Are White, All the Blacks Are Men, But Some of Us Are Brave: Black Women's Studies, 1982. Essa obra foi uma das primeiras coletâneas de artigos acadêmicos sobre feminismo negro nos Estados Unidos.
} 
interseção entre racismo, sexismo e colonialidade, que tem efeitos concretos materiais como subjetivos, na medida em que nossa imagem é socialmente construída de forma distorcida, baseando-se em mitos e estereótipos.

Desfazer material e simbolicamente estas subordinações não é tarefa simples. Para além do advertido por Lélia Gonzalez (1984) — sobre o fato da representação estereotipada da mulher negra estar calcado no imaginário da sociedade brasileira, numa relação entre consciente $\mathrm{x}$ inconsciente coletivo - existe, ainda, a dificuldade em disputar outra narrativa.

Por muito tempo a única perspectiva epistemológica reconhecida era produzida a partir de uma cosmovisão muito bem definida - branca e masculina -, já que o racismo provoca um verdadeiro "epistemicídio" de intelectos negros, enquanto o sexismo desqualifica o pensamento de mulheres. A própria capacidade de de dar nomes às coisas é a expressão de uma situação de poder. Assim, a possibilidade de ordenar o mundo a partir de seus próprios termos, singulares ou coletivos, é uma situação de privilégio (WERNECK, 2005) e seus impactos são imensos:

"Se não houve vontade de saber em torno da história da mulher, quadrupliquemos essa "indisposição" no que toca à constituição da memória das mulheres negras para tentarmos avaliar o perímetro dos vazios e das lacunas. Ao executar tal tarefa, veremos que o estrago no campo das representações é incalculável" (BORGES, 2009, p. 14)

Há, portanto, uma dinâmica de não reconhecimento da produção intelectual de negros, em geral, e de mulheres negras, em particular. Assim, muitas das questões históricas que nos dizem respeito não são enfrentadas pela narrativa oficial, já que as experiências dos seus narradores não acessam a especificidade dos sujeitos marcados pelas opressões de raça, classe e gênero. Ou pior: mesmo quando alguma reflexão é produzida sobre nós, não raras vezes a perspectiva é de objetivação de nossos corpos e romantização das violências perpetradas sobre eles. O papel das mulheres negras nunca é narrado a partir de uma lente que considera a articulação política e a resistência histórica desempenhada por esse grupo, sempre narrado a partir da ótica da passividade. 
Lélia Gonzalez (1984), em pretuguês, nos ilustra esse processo muito bem. No texto "Racismo e sexismo na cultura brasileira", a autora traz uma epígrafe que, de cara, evidencia o processo de identificação do dominado com o dominador, reflexão que é explorada a fundo ao longo do seu texto. Para além do que conta, a epígrafe também denuncia o confisco da palavra de negros/as dentro da academia: teóricos que falam por nós, sobre nós. Especialmente para nós, mulheres negras, este processo é auto-evidente, já que somos "faladas, definidas e classificadas por um sistema ideológico de dominação que nos infantiliza". (GONZALEZ, 1988b). Justamente pelo fato de estarmos no nível inferior da hierarquia social, existe um movimento de supressão da nossa humanidade, nos negando não só os espaços de produção de poder, mas também o direito de sermos sujeitos do nosso próprio discurso e da nossa própria história (GONZALEZ, 1988b).

Nesta proposta de pensar criticamente as dinâmicas de poder e vozes subalternizadas, e dialogando com Lélia Gonzalez, cabe retomar o trabalho de Gayatri Spivak (2010). Apesar de sua obra estar em uma disputa em termos pós coloniais no contexto do sul asiático, podemos utilizar sua análise para refletir nosso lugar enquanto Améfrica Ladina. O debate que permeia "O subalterno pode falar?", uma de suas obras mais difundidas, é justamente a relação travada entre violência epistêmica, poder e agência. Como o nome do próprio livro indica, a questão que se coloca é a seguinte: o subalterno, enquanto tal, consegue se fazer reconhecer enquanto sujeito?

Para responder a esta pergunta é necessário ter como premissa a ideia de que o modelo de sujeito soberano forjado no pensamento moderno colonial é construído por um modelo totalizante, mediado por uma linguagem hegemônica. Sendo assim, toda a linguagem que permite interação com o interlocutor é a linguagem hegemônica, que é justamente a do sujeito privilegiado. A voz é entendida por Spivak como local coletivo de agência e, desta forma, o subalterno, em seus próprios termos, não consegue colocar sua voz, sendo constantemente intermediado e reivindicado. $\mathrm{O}$ que estamos falando aqui, porém, não é meramente sobre a 
possibilidade ou impossibilidade de fala e escuta em seu sentido literal. Estamos falando de agência, já que alguns corpos não têm suas vozes reverberadas enquanto ação política. O desafio, portanto, é muito maior do que só dar voz ao silenciado, mas criar canais possíveis de reconhecimento e registro de ação política.

A colonialidade do saber, responsável por estes movimentos de infantilização e silenciamento do subalterno, informam o modo de produção do conhecimento e os movimentos ditos progressistas, dentre eles, o feminismo. Como aponta Espinosa-Miñoso (2014), o pensamento feminista clássico foi produzido por um grupo específico de mulheres, aquelas que gozaram do privilégio epistêmico graças a sua origem de classe e raça. E, além de ser construído a partir de certa visão de mundo muito específica, a colonialidade discursiva dos feminismos ocidentais também geram um "estado de mudez e subrepresentação das mulheres subalternas latinoamericanas" (MONJE, 2017, p. 137). Assim, podemos concluir que racismo, sexismo, colonialidade e eurocentrismo estão relacionados de tal modo que afetam o modo de formação do conhecimento, formando uma "hegemonia do conhecimento ocidental que tem um caráter universalista e naturalista da sociedade moderna-capitalista-colonial" (MONJE, 2017, p. 138). Em outras palavras, existe, como apontado por Sueli Carneiro (2005), um certo "eu hegemônico" que pauta as discussões, fazendo com que as relações de saber-poder sejam produzidas no sentido universal, silenciando todas as perspectivas que se afastam da régua da humanidade.

Muitas são as intelectuais e ativistas que denunciam o caráter excludente e, inclusive, racista do feminismo hegemônico (GONZALEZ, 1988b; CARNEIRO, 2003; WERNECK, 2005; CURIEL, 2007; DAVIS, 2016). Nesta abordagem universalizante, feministas utilizam o gênero como a única lente para avaliar a subordinação, como se esta fosse o único vetor de opressão que toda e qualquer mulher está sujeita. Neste sentido, Espinosa-Miñoso (2014) entende que são aplicáveis, à grande maioria das epistemólogas feministas, as mesmas críticas que elas mesmas fizeram aos 
homens da ciência, na medida em que conformam uma dinâmica de racismo de gênero:

\begin{abstract}
"feministas blancoburguesas la categoría superior y relevante es la de género, terminan asumiendo que su punto de vista es el que representa el de "las mujeres" en su totalidad. Con ello se creen libres de aplicarse a sí mismas la crítica que ya hicieron a quienes, desde su punto de vista, representan una posición de poder. Basándose solamente en el análisis del género como categoría analítica que permitiría explicar la subordinación de (todas) las mujeres, las teóricas feministas no han podido observar y ser críticas de su propio privilegio dentro del grupo de las mujeres y del sesgo de raza y clase de la teoría que construyen. Ello sería un buen ejemplo de lo que he denominado racismo del género" (ESPINOSAMIÑOSO, 2014, p.10)
\end{abstract}

Se o movimento feminista exclui mulheres negras por, muitas vezes, ser racista, por outro lado, o movimento negro também não está infenso ao sexismo. Com a palavra, mais uma vez, Lélia Gonzalez:

"Mas é exatamente essa participação que nos leva a consciência da discriminação sexual. Nossos companheiros de movimentos reproduzem as práticas sexistas do patriarcado dominante e tratam de excluir-nos dos espaços de decisão do movimento. E é justamente por essa razão que buscamos o MM [movimento de mulheres], a teoria e a prática feministas, acreditando aí encontrar uma solidariedade tão importante como a racial: a irmandade. Mas o que efetivamente encontramos são as práticas de exclusão e dominação racista [...]. Somos invisíveis nas três vertentes do MM[1]; inclusive naquela em que a nossa presença é maior, somos descoloridas ou desracializadas, e colocadas na categoria popular (os poucos textos que incluem a dimensão racial só confirmam a regra geral)" (GONZALEZ, 1988b)

Além disso, no quesito da violência doméstica, há uma tendência apresentada por certos grupos do movimento negro em ler situações de violência doméstica contra mulheres negras a partir de uma lente unicamente centrada na raça, como se fosse outra manifestação do racismo (CRENSHAW, 1993).

Como o mote do feminismo negro norte americano que dá nome a esta seção evidencia, os movimentos sociais antiracista e antisexista normalmente são atravessados por uma dupla universalização, o que invisibiliza mulheres negras: dentro do movimento feminista, o sujeito universal é a mulher branca, enquanto dentro do movimento negro, a centralidade é dada no homem negro. Estes dois grupos, não raras vezes, 
possuem agendas distintas, fazendo com que seja difícil politizar as questões das mulheres negras (CRENSHAW, 1993).

E cumé que a gente fica? Quando nos propormos a dar visibilidade e politizar as questões das mulheres negras, uma lente de análise que parece interessante é a da interseccionalidade e da imbricação, que será apresentada a seguir.

\subsection{Das muitas formas de resistência: Interseccionalidade e Imbricação como possibilidades da visibilização}

Apesar da ideia de interseccionalidade ter estado presente para as mulheres negras há muito tempo, o termo em si foi cunhado na década de 90 por Kimberlé Crenshaw. Segundo a autora,

\footnotetext{
"A interseccionalidade é uma conceituação do problema que busca capturar as consequências estruturais e dinâmicas da interação entre dois ou mais eixos da subordinação. Ela trata especificamente da forma pela qual o racismo, o patriarcalismo, a opressão de classe e outros sistemas discriminatórios criam desigualdades básicas que estruturam as posições relativas de mulheres, raças, etnias, classes e outras" (CRENSHAW, 2002, p. 177)
}

A autora (2016) relata que foi a partir de um encontro com uma mulher chamada Emma de Graffenreid que este termo ganhou vida. Emma não foi contratada por uma montadora de automóveis, que processou a empresa alegando discriminação de gênero e raça. O juiz, porém, julgou o caso improcedente, sob o argumento de que não havia discriminação, já que o empregador contratava homens e mulheres. O problema que esta argumentação traz — e que é justamente o que Emma estava tentando provar - era que as pessoas negras contratadas, normalmente para trabalhos mecânicos, eram todos homens, enquanto as mulheres contratadas, para trabalhos administrativos, eram todas brancas. A situação de Emma, neste sentido, era particular e apenas uma lente que fosse capaz 
de ver estas duas categorias em conjunto poderia combater a dupla discriminação que estava sofrendo.

$\mathrm{Na}$ literatura da época, não havia um nome ou uma categoria que desse conta desse problema. E, como Kimberlé (2016) descreve,

\begin{abstract}
"Ocorreu a mim que uma simples analogia a uma interseção possibilitaria que os juízes pudessem ver o dilema de Emma. Porque Emma era tanto mulher como negra, ela estava localizada exatamente onde estas duas pistas se encontram, experimentando simultaneamente o impacto do tráfego da companhia de gênero e de raça. A lei é como uma ambulância que aparece e está pronta para tratar Emma somente se puder ser mostrado que ela foi penalizada no tráfego que diz respeito à raça ou no tráfego de gênero, mas não onde essas estradas se interconectam"
\end{abstract}

Deste modo, as mulheres negras são atravessadas por duas formas de opressão que não são visíveis na lente hegemônica e é justamente esta invisibilidade que contribui para a maior vulnerabilidade. Sendo é invisível, não é possível ver o problema e se não é possível ver o problema, não é possível superá-lo (CRENSHAW, 2016).

Parafraseando o poeta martinicano Aimé Césaire, podemos dizer que as duas maneiras de ocultar a existência e experiência de mulheres negras é por segregação ou por diluição no universal ${ }^{12}$. E é justamente para dar conta destas formas de invisibilização que Kimberlé desenvolve os conceitos de superinclusão e subinclusão. Nesse sentido, a superinclusão ocorre quando uma condição específica vivenciada por um certo subgrupo de mulheres é absorvida pela estrutura de gênero, ou seja, é considerada como um problema de todas as mulheres. O impacto deste mecanismo é que o problema enfrentado fica esvaziado de especificidade e, assim, a forma de enfrentar acaba ficando mais genérico e, portanto, mais ineficaz do que deveria. À título de ilustração, no caso brasileiro, podemos trazer a violência obstétrica, esterilização forçada e morte materna por causas evitáveis, que são centralmente tratadas a partir da dimensão de gênero e só perifericamente considera-se as dimensões de raça e classe das mulheres

\footnotetext{
${ }^{12}$ No original: "Há dois modos de nos perdermos: ou emparedados pela segregação no particular ou pela diluição no universal”, in Carta a Maurice Thorez, Aimé Césaire (1956).
} 
que majoritariamente são mais vulneráveis a estas questões (BERNARDES \& ALBUQUERQUE, 2014).

No segundo caso, a subinclusão ocorre quando um subgrupo de mulheres enfrenta um problema de gênero que não é visto como tal, já que as mulheres dos grupos dominantes ou os homens dos grupos a que pertencem não enfrentam estes mesmos problemas. Essa lente possibilita enxergarmos mulheres que estão em situação de vulnerabilidade, mas que são invisibilizadas, como, por exemplo, mulheres presas, mulheres que usam drogas e/ou mulheres ligadas ao tráfico de drogas. Todas estas mulheres não são vistas como mulheres per se. É como se gênero não compreendesse parte de suas identidades e, assim, suas experiências são englobadas por outras categorias, como raça e classe (RICHIE, 2010).

Interessante observar como o conceito de interseccionalidade permite atentar para a invisibilidade de mulheres negras em diversas esferas. Crenshaw cunha este termo dentro de uma análise jurídica, mas a partir dele podemos pensar, por exemplo, como os próprios movimentos sociais são cegos à superposição de diversas formas de opressão. Nesse ponto, é necessário atentar ao fato de que não se trata propriamente de uma falha em adicionar às análises as dimensões de raça ou classe. Trata-se de uma limitação em termos que os movimentos sociais deveriam estar atentos. Justamente porque mulheres negras experimentam o racismo de forma distinta daquela que afeta os homens negros, e o sexismo também de forma diversa que as mulheres brancas, os próprios movimento antirracista e feminista se tornam limitados. Uma visão, portanto, que apenas "adicione" uma análise não ajuda em nada, sendo necessário que estes movimentos reconheçam que a própria forma de experimentar gênero e raça por mulheres negras é diferente (CRENSHAW, 1993).

Necessário tornar suficientemente explícito algo que o conceito de interseccionalidade já evidencia: não há hierarquia de opressões e, mais ainda, as opressões não são necessariamente equivalentes. Isso porque "raça sexualidade, origem ou classe não são elementos que quantitativa, ou 
qualitativamente, se possam mensurar" (MENDES, 2014, p. 100). Porém, igualmente importante entender que, como bem resume Lélia Gonzalez com a frase "depois de tudo, sou feminista", a questão racial, para as mulheres negras, tende a assumir uma certa centralidade na medida em que é a categoria que informa hierarquias de humanidade.

\subsubsection{Ajustando as lentes: uma leitura dos dados sobre violência contra mulheres a partir da imbricação}

Segundo o Mapa da Violência de Mulheres 2015 (WAISELFISZ, 2015, p. 27), dentre os 83 países que divulgam dados confiáveis sobre taxas de homicídio de mulheres, 4 dos 5 primeiros maiores números são latino americanos — são eles: El Salvador, Colômbia, Guatemala e Brasil. A plena compreensão dos causas que contribuem para este resultado desastroso só será possível se lermos os dados a partir das dinâmicas da colonialidade que inscrevem as relações de gênero. Para isso, propomos a leitura desses números a partir do conceito de imbricação. Segundo Ochy Curiel,

\footnotetext{
"Compreender a imbricação das opressões não se trata de colocar categorias que conformam uma somatória de experiências, ou uma interseção de categorias analíticas (CRENSHAW, 1993), se trata de entender como estas têm atravessado historicamente nossa região desde o colonialismo até a colonialidade contemporânea e como elas têm se expressado em certos sujeitos que não têm tido privilégios de raça, classe, sexo e sexualidade, como no caso das mulheres negras, indígenas e camponesas da região" (CURIEL, 2016, p. 80, tradução nossa)
}

A autora disputa o conceito de interseccionalidade, na medida em que é um conceito que conjuga as análises de múltiplas opressões mas que, de certa maneira, é míope em relação às dinâmicas de poder forjadas pela colonialidade e imperialismo. Assim, o fato dos países com mais feminicídio no mundo serem latino-americanos não é mera coincidência. Os dados não nos deixam dúvidas: o brutal processo histórico de formação das 
Américas e a consequente instituição de modelos de hierarquia relacionadas ao colonialismo, imperialismo e sexismo na região até hoje definem as possibilidades de existência de mulheres. O conceito de imbricação, portanto, vem de uma reflexão trazida pelo feminismo e pensamento decoloniais, quando a agenda é interceptada pelas discussões do imperialismo e colonialidade.

Neste cenário, o Brasil apresenta um total de 4,8 homicídios por 100 mil mulheres, ocupando a $5^{\mathrm{a}}$ posição no ranking. Além disso, através do recorte racial, a pesquisa demonstrou um dado extremamente sintomático: enquanto número de mulheres brancas vítimas de homicídio caiu 9,8\% em 10 anos (de 2003 a 2013), o número de mulheres negras mortas neste mesmo período aumentou 54,2\% (p. 30).

A centralidade da questão racial é reconhecida pelo próprio relatório:

\footnotetext{
Nos diversos Mapas da Violência em que abordamos a questão da incidência da raça/cor na violência letal, para o conjunto da população, concluímos que:

a. Com poucas exceções geográficas, a população negra é vítima prioritária da violência homicida no País.

b. As taxas de homicídio da população branca tendem, historicamente, a cair, enquanto aumentam as taxas de mortalidade entre os negros.

c. Por esse motivo, nos últimos anos, o índice de vitimização da população negra cresceu de forma drástica. (WAISELFISZ, 2015, p. 29)
}

Como fica evidente, a herança colonial racista e sexista ainda projeta sobre mulheres negras todos os mitos anteriormente pactuados, fazendo com que nossos corpos sejam objetificados, hipersexualizados e ceifados de várias formas. Seguindo outras estatísticas criminais, a perspectiva também é desoladora: mulheres negras constantemente figuram entre as principais vítimas de estupro e mortes violentas no país. Como consta no Dossiê Mulher 2018, pesquisa divulgada pelo Instituto de Segurança Pública (ISP), as mulheres negras têm mais chance de serem alvo de violência no Rio de Janeiro (MANSO, MORAES, 2018). Os dados evidenciam que as mulheres pretas e pardas são a maioria entre as vítimas de homicídio doloso $(60,6 \%)$ - quase o dobro do percentual de mulheres brancas $(30,8 \%)$ - tentativa de homicídio $(57,7 \%)$, lesão corporal $(53,3 \%)$, estupro $(56,3 \%)$ e ameaça 
$(49,9 \%$ ). Ou seja, são a maioria das vítimas de crimes contra a vida, dignidade sexual e liberdade individual.

Como é presumível, as reflexões em relação à violência de gênero raramente possuem recorte racial ou de classe. Quando possuem, a ênfase é dada nas desigualdades quanto às possibilidades de conseguir romper com o ciclo de violência. As pesquisas acima, contudo, vão além deste dado e confirmam a maior vulnerabilidade de mulheres negras. Para fins de investigação, uma das hipóteses que podemos levantar é a influência conjunta do racismo e da estrutura de classes para a produção deste resultado, na medida em que ambos funcionam como um verdadeiro motor impulsionador desse sistema de opressão (DAVIS, 2016, p. 177 e 201).

Tal dinâmica é histórica. Desde o imaginário colonial, homens brancos de classes sociais abastadas são construídos a partir de um imaginário onde é possível "tirar vantagem" de mulheres que eles consideram inferiores (DAVIS, 2016, p. 201). Além disso, no pós escravidão, as legislações anti estupro elaboradas nos EUA e em outros países capitalistas, visavam proteger a honra dos homens que "corriam o risco" de verem suas filhas e esposas sendo violentadas. Digno de honra, contudo, só o homem branco de classe alta, já que mesmo dentro de uma construção falocêntrica o homem negro era desconsiderado (DAVIS, 2016, p. 177). Assim, as legislações acabavam por privilegiar mulheres brancas, a despeito de todo o histórico de violência sexual que assombrou mulheres negras escravas. 


\section{Capítulo 3. Dororidades: Violência Doméstica e Familiar contra mulheres negras}

Mas qual a finalidade, no nosso caso, de ter um novo conceito - Dororidade? Será que, como Mulheres Feministas, a Sororidade não nos basta? A pergunta está no ar.

O caminho que percorro nessa construção conceitual me leva a entender que um conceito parece precisar do outro. Um contém o outro. Assim como o barulho contém o silêncio. Dororidade, pois, contém as sombras, o vazio, a ausência, a fala silenciada, a dor causada pelo Racismo. E essa dor é Preta.

Dororidade carrega no seu significado a dor provocada em todas as Mulheres pelo Machismo. Contudo, quando se trata de Nós, Mulheres Pretas, tem um agravo nessa dor. A Pele Preta nos marca na escala inferior da sociedade. E a Carne Preta ainda continua sendo a mais barata do mercado. É só verificar os dados...(PIEDADE, 2017, p. 16-17)

Quando nos propomos a discutir violência doméstica com um aporte interseccional devemos partir da premissa de que, embora a violência de gênero atinja potencialmente todas as mulheres, as mulheres negras são “mais vitimadas pelas práticas desencadeadas pela violência de gênero, nas suas implicações com a violência contra a mulher, e pela ainda incipiente resposta ofertada pelo sistema de justiça aos casos" (FLAUZINA, 2015, p. 122). Em outras palavras, a própria dinâmica de opressão é alterada, já que o peso do racismo acaba por articular um tipo de vitimização particular. Além disso, também há barreiras visíveis e invisíveis que condicionam a não possibilidade de rompimento com o ciclo de violência. No nível material, temos as barreiras econômicas. Em nível imaterial, temos impacto do racismo que não raro formata a auto estima e subjetividade de mulheres 
negras, no sentido de aceitar pouco e ainda se culpar pela violência sofrida (SANTOS, 2014, p. 148).

$\mathrm{Na}$ tentativa de dar luz à sobreposição de violências, podemos dialogar com o trabalho desenvolvido pelo Grupo "Gênero, Democracia e Direito", que se propôs a analisar a aplicação da Lei 11340 (Lei Maria da Penha) no cotidiano dos Juizados de Violência Familiar e Doméstica contra a Mulher de Duque de Caxias, de Niterói e do Rio de Janeiro. A partir do método story telling, o artigo de uma das pesquisadoras do grupo, Mariana Albuquerque (2015), resgatou narrativas que denunciam um contexto de sobreposição de violências, narrativas essas que não podem alcançadas pelos métodos tradicionais de estudo de violência contra a mulher. Dentre uma dessas tantas vozes acessadas através da análise dos procedimentos e formulários preenchidos no contexto de requerimento de Medidas Protetivas de Urgência, encontramos a história de Lúcia. Narra Mariana:

\begin{abstract}
"Quando a filha de Lúcia (nome fictício) engravidou e se recusou a contar quem era o pai, Lúcia nem imaginou que este era seu próprio companheiro. Só à medida que a neta crescia, e as semelhanças chamavam atenção, que se descobriu que ele estuprava regularmente a enteada desde os 13 anos. Lúcia, então, colocou-o para fora de casa. Foi quando passou, ela, a ser o alvo da violência direta. Para além das ameaças contra a sua vida e integridade física, seu excompanheiro começou a importunar seu empregador, tentando acarretar sua demissão. Lúcia é empregada doméstica, e depende desse emprego para seu sustento, da filha e da neta. Ele também começou a criar intrigas sobre Lúcia com os traficantes que dominam a comunidade na qual Lúcia mora. Agora, ela teme por sua vida triplamente: teme o desemprego e a carência financeira, teme as ameaças do ex-companheiro, teme as ameaças dos traficantes" (ALBUQUERQUE, 2015, p. 1)
\end{abstract}

De alguma forma, as lentes hegemônicas não estão ajustadas para enxergar as violências vivenciadas por mulheres como Lúcia, ainda que experiências como as dela não sejam exceção na sociedade brasileira. Nos chama atenção os desdobramentos que a violência doméstica pode ter para alguém que, a um só tempo, vivencia um contexto de opressão de gênero, raça e classe, além sofrer diretamente os efeitos da atual política pública de guerra às drogas, que entrega comunidades inteiras ao poder paralelo exercido por traficantes. A história de Lúcia não é um ponto fora da curva. 
Raridade, na verdade, é a existência de lentes que estejam ajustadas para enxergar as violências sofridas por Lúcia e outras milhares de mulheres.

Aliás, é igualmente possível supor que a existência do poder paralelo nas favelas brasileiras seja um grande empecilho nas possibilidades de acionar o Estado em um contexto de violência doméstica. É que, nas áreas dominadas pelo tráfico, chamar atenção estatal com todo seu aparato (polícia, oficial de justiça, etc) pode ser um passo perigoso que, com razão, a maioria das mulheres não quer pagar para ver.

Com o intuito de facilitar a compreensão das variadas dinâmicas de violência atravessadas por mulheres negras que discutimos acima, trago aqui a dinâmica do "Power and Control Wheel". Este projeto didático foi criado em 1984, por funcionários do Projeto de Intervenção no Abuso Doméstico, nos Estados Unidos, que pensaram em uma maneira de desenvolver um novo currículo para grupos de homens acusados de violência doméstica e de mulheres vítimas. Neste contexto, a figura abaixo ajuda a identificar as formas de agressão, exemplificando abusos na esfera física, emocional, sexual, intimidatória, etc. 


\section{GRÁFICO 1 - Violência e abuso dentro de relações}

\section{heterosexuais $^{13}$}

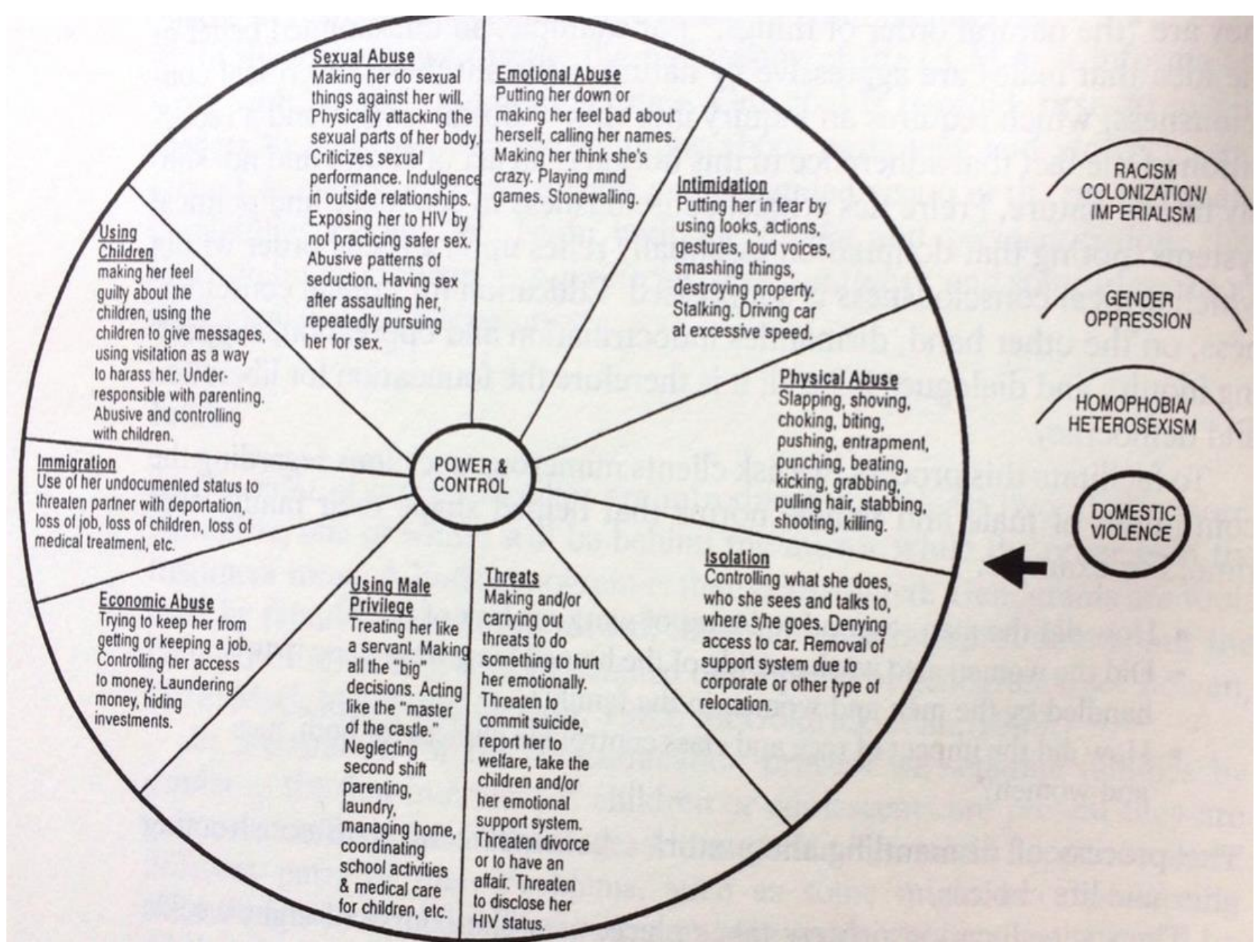

Interessante observar que a roda apresenta uma das dimensões de violência doméstica, mas ainda há três outras dimensões, que trazem dinâmicas específicas: homofobia/heterosexismo, opressão de gênero e racismo/colonização/imperialismo.

A figura 2, mostrada abaixo, traz outra dimensão da violência doméstica levando em conta os modos pelos quais as mulheres são afetadas pelo

${ }^{13}$ Gráfico retirado do artigo: ALMEIDA, R. V.; LOCKARD, J. The Cultural Context Model: A New Paradigm for Accountability, Empowerment, and the Development of Critical Consciousness against Domestic Violence. In: SOKOLOFF, N. J; PRATT, C. (Org.) Domestic Violence at the Margins: Reading on Race, Class, Gender, and Culture. New Jersey: Rutgers University Press, 2010. p. 306. 
racismo na esfera privada e pública, demonstrando justamente que "no ambiente doméstico, o racismo passa a ser um significante decisivo na potencialização das agressões a que são submetidas as mulheres negras" (FLAUZINA, 2015, p. 143).

\section{GRÁFICO 2 - Violência e abuso contra mulheres negras ${ }^{14}$}

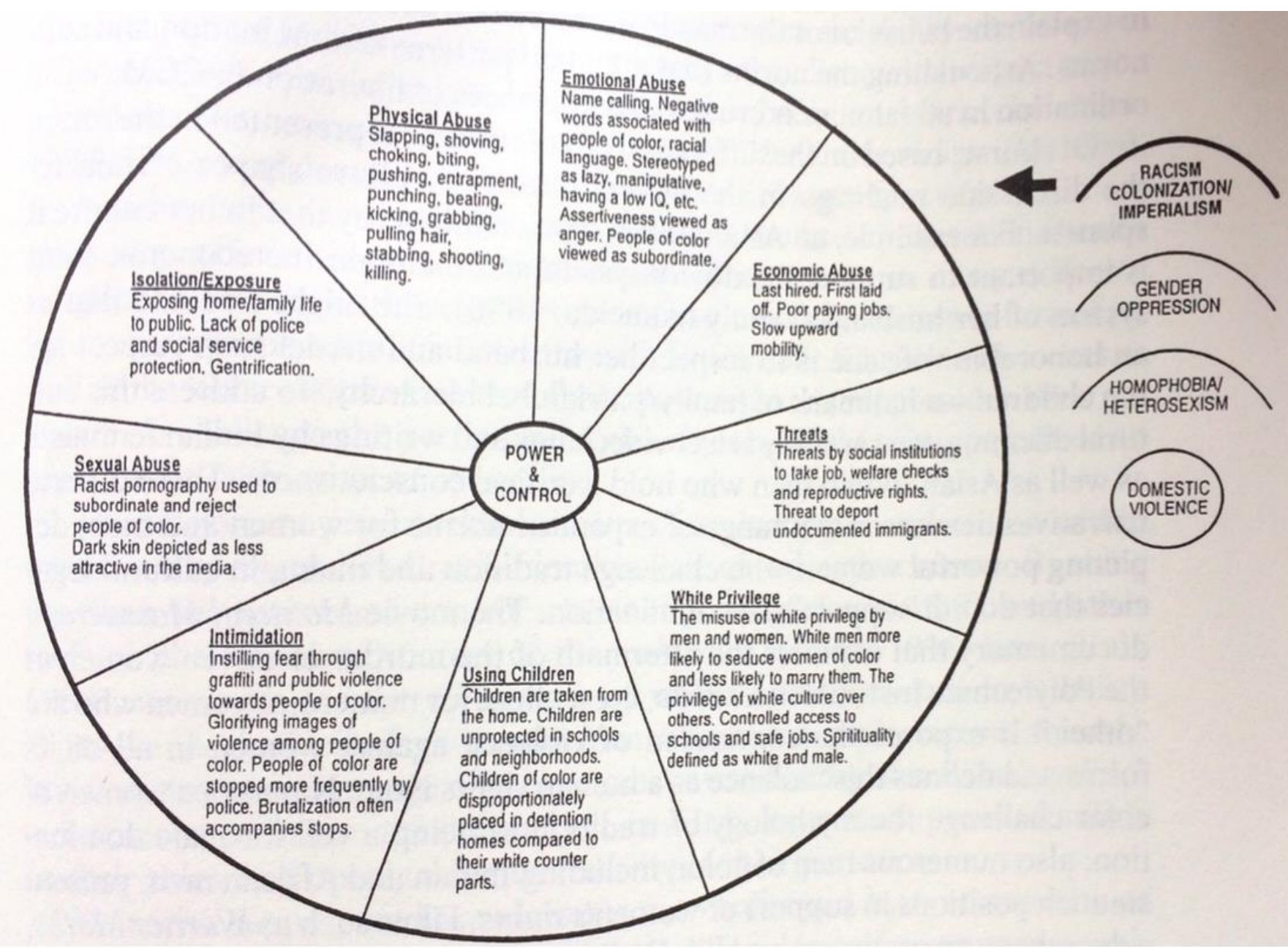

Nesse sentido, também vai a investigação sociológica de Bruna

Pereira e Tânia de Almeida (2012) que pontuam as singularidades das agressões domésticas direcionadas às mulheres negras:

${ }^{14}$ Gráfico retirado do artigo: ALMEIDA, R. V.; LOCKARD, J. The Cultural Context Model: A New Paradigm for Accountability, Empowerment, and the Development of Critical Consciousness against Domestic Violence. In: SOKOLOFF, N. J; PRATT, C. (Org.) Domestic Violence at the Margins: Reading on Race, Class, Gender, and Culture. New Jersey: Rutgers University Press, 2010. p. 307 


\begin{abstract}
"São representações que orientam posturas e práticas violentas contra mulheres pretas e pardas por parte de seus companheiros, e que abrangem: constante fiscalização de sua sexualidade, na medida em que são consideradas hipersexualizadas; a negação de sua sexualidade, uma vez que seus atributos estéticos estão distantes daqueles atribuídos às mulheres brancas, tomados como padrão de beleza; a violência sexual, como forma de humilhação e/ou pela desconsideração de sua humanidade; as humilhações degradantes, com ou sem presença do insulto racial, ancoradas na percepção de seu status socialmente subalterno; a exploração econômica dos recursos obtidos pelo seu trabalho remunerado, com base na imagem de que são trabalhadoras incansáveis e que o mero fato de que se relacionar com elas constitui, por si só, um favor, que deve ser retribuído; a exploração de seu trabalho no âmbito doméstico, com base na imagem de que são naturalmente cuidadoras; a agressão física brutal, que parte do pressuposto de sua força física avantajada" (ALMEIDA e PEREIRA, 2012, p. 58-59)
\end{abstract}

No livro "Tramas e Dramas de gênero e de cor: a violência doméstica e familiar contra mulheres negras", Bruna Pereira (2016) vai ainda mais fundo na investigação sobre em que medida o racismo informa e ressignifica a esfera doméstica. Dentre outras coisas, nos é apresentado a urgência em pensar as dimensões da violência doméstica em outros termos. Trata-se de necessidade de aumentar nosso entendimento do que é este fenômeno, como forma de alcançar àquelas mulheres que estão longe da régua da branquitude e, portanto, da feminilidade clássica.

A partir do relato de uma das entrevistadas, Bruna Pereira dá voz à Emília, mulher negra, casada com um funcionário público, negro, com quem tem quatro filhos e três filhas. Ela menciona a prática, por parte dele, de agressões físicas (inclusive sexuais), psicológicas e morais. A partir do momento em que seu marido descobriu seu envolvimento com um homem branco, a violência se agravou e, dentro das humilhações e agressões, também houve ofensas raciais. Narra ela:

"Ele dizia assim que não ia mais se envolver com mulher preta, que mulher preta só serve pra cama [...] Ele se sentiu então diminuído porque essa pessoa tinha outra cor. Não poderia ter sentimento, ou mesmo que fosse uma relação sexual, não podia ser com alguém de outra raça. Então aí ele mesmo tratou de trazer o racismo em relação a mim. Que preta era vagabunda, que preta era descarada, que era por isso que os homens pegavam as mulheres negras e sempre tinham casinhos com elas, que isso era uma coisa constante. E ele me dizia abertamente que nunca mais ele ia se relacionar com uma mulher negra". (PEREIRA, 2016, p. 136) 
Quando a autora pergunta, na opinião da entrevistada, o que seria diferente na relação conjugal e nas dinâmicas de violência se ela fosse branca, Emília responde:

\footnotetext{
"Bom, pelo menos eu não ia ter que escutar que meu novo pretendente estaria comigo só porque eu era negra gostosa, que ele só ia querer ficar comigo sexualmente. Claro que ia ter diferença. Ele não ia dizer que não ia nunca mais se relacionar com uma mulher negra, que mulher negra é tudo vagabunda, e que era por isso que os homens diziam isso. Porque mesmo não dito, parece que tem um consenso masculino de que mulher negra é boa para ir pra cama. Pra casar mesmo tem que ser branca. Então, ele me disse que ele que foi otário que casou com uma mulher negra" (PEREIRA, 2016, p. 141)
}

O relato em questão é potente na medida em que, em primeira pessoa, demonstra o impacto de estereótipos e imagens controladores numa situação de violência doméstica. O marido de Emília, ao se sentir ameaçado, aciona as representações estereotipadas e imagens controladoras referentes às mulheres negras, que dizem respeito, principalmente, à sexualidade e a subalternidade na escala social (PEREIRA, 2016). Por este relato, podemos perfeitamente apreender como um imaginário coletivo pode afetar a esfera privada, dando outros moldes para a situação de violência. Aqui, podemos ver como as dinâmicas de subordinação de estereótipos e imagens controladoras que nos referimos no capítulo 2 agem no imaginário coletivo da sociedade brasileira. Ainda no relato do marido, ele afirma que os homens em geral falam que mulher preta é "vagabunda" e "descarada". Nesta fala, ele evidencia, portanto, "a existência de um discursos sobre a sexualidade e o erotismo das mulheres negras que é socialmente compartilhado, e que lhes atribui uma sexualidade desviante, excessiva" (PEREIRA, 2016, p. 142).

\subsection{Dos essencialismos legais e do movimento feminista}

A primeira forma de invisibilizar mulheres negras é dada por uma leitura essencializada do que seja violência doméstica. Como indicamos no 
capítulo 2, o discurso feminista é marcado por um certo "eu-hegemônico", onde o sujeito privilegiado confunde suas condições com as condições de todo o grupo e, assim, o que diria respeito à "todas as mulheres", na verdade, quer dizer "todas as mulheres brancas, ocidentais, heterosexuais, classe média”. As campanhas de combate à violência doméstica e sexual contra as mulheres também são politizados neste sentido universalista. Argumenta-se que "todas as mulheres" podem ser vítimas desse crime, o que parece verídico e positivo na medida em que retira o estereótipo de que situações de violência doméstica são específicas de comunidades negras e pobres. Por outro lado, o que esta abordagem tenta esconder é a hierarquia de humanidade em que se ancora. Como bem fala Ana Flauzina (2016), dor negra não registra e, assim,

\footnotetext{
"Trata-se de sofrimento que precisa ser mediado por um corpo branco, e consequentemente humano, para se fazer inteligível. É sofrimento que sempre carece de tradução para sua apreensão completa, de medida que lhe dê proporção. Quanto vale a dor negra em branco?” (FLAUZINA, 2016, p. 65)
}

Como forma de sensibilizar a opinião pública e angariar mais adeptos à causa, o "pode acontecer com todas as mulheres", de fato, quer dizer "pode acontecer com mulheres privilegiadas". O resultado disso é que esta universalização do discurso tem um efeito concreto para mulheres que estão fora da régua da humanidade, desta forma, não só a luta, mas as políticas públicas são construídas a partir da imagem de mulheres que já são privilegiadas na estrutura social e todas as campanhas são baseadas em sua necessidade (RICHIE, 2010). Em outras palavras, há universalização do discurso da violência, que gera a centralidade na mulher branca de classe média e um consequente "esquecimento" no sentido de pensar e promover condições materiais para que todas as mulheres tenham possibilidade de romper com o ciclo da violência. A legislação que é elaborada sem pensar na especificidade dos sujeitos atravessados por diversas eixos de subordinação, partindo de uma perspectiva universal, dessa forma, não irá atingir as mulheres negras (CRENSHAW, 1993). 
Diante da invisibilização causadas por uma abordagem essencialista, qual é especificamente o papel do Direito? Em outras palavras, como as legislações respondem a isso? A jurista norte-americana Angela Harris (1990) produz uma reflexão importante sobre como os essencialismos são instrumentalizados pela Teoria Feminista e Teoria do Direito. No artigo "Race and Essentialism in Feminist Legal Theory", a autora indica que ambos os campos se valem da abstração e engendram uma voz com pretensão universal mas que, na verdade, dizem respeito a sujeitos privilegiados. A voz do direito é uma voz autoritária e coercitiva na sua tentativa de falar por todos, assim como a teoria feminista, em muitos aspectos. Nesse sentido, o "homem médio" é o homem branco, heterossexual, proprietário; e, na teoria feminista, a "mulher" é a branca, heterossexual, classe média, cis.

A autora ainda aponta como a produção teórica de autoras feministas que possuem trabalhos conhecidos e respeitados, como Catherine MacKinnon, contribuem para o silenciamento da experiência das mulheres negras, justamente por serem ahistóricas e construídas a partir de uma análise unitária de gênero, totalmente destituída de dimensões de raça, classe, orientação sexual e outras experiências.

A pergunta que fica é a seguinte: se o essencialismo produz efeitos tão perversos, produzindo silenciamentos e reprodução de várias violências, por que ele ainda permanece tanto no feminismo enquanto movimento social e teoria? Segundo Harris, por vários motivos. Em primeiro lugar, particularmente para feministas brancas, o essencialismo é cômodo, já que a própria cultura dominante é construída nesses termos. Isso significa não ter muito trabalho, não se deixar afetar pelas experiências de mulheres negras e, principalmente, não questionar sua branquitude, com todo o risco que esta empreitada gera. Em segundo lugar, especialmente para mulheres privilegiadas, o movimento feminista se tornou um local emocional e espiritual, um local de segurança e harmonia. Um lugar de conforto, não de conflito. Trazer a experiência de outros corpos, portanto, seria lidar com a 
diferença que pode gerar divergências. Em terceiro lugar, o feminismo essencialista oferece para as mulheres um conforto intelectual, com a oportunidade de se jogar em termos familiares tanto entre elas como em relação aos homens. Finalmente, cognitivamente, precisamos de categorias simplificadas, e uma categoria unificada de mulher ajuda a organizar a experiência, mesmo com o custo de negar algumas delas. Enfim, é uma alternativa ao caos, diante ao pluralismo de perspectivas.

\subsection{A Lei Maria da Penha}

Em 1984, a bioquímica nordestina Maria da Penha Maia Fernandes sofreu duas tentativas de homicídio: uma descarga elétrica durante o banho e um tiro de arma de fogo que a deixou paraplégica. Ambas as agressões foram cometidas por seu marido à época. Passados 15 anos da ocorrência dos fatos, o processo ainda seguia sem resposta pelo judiciário brasileiro. A partir de esforços por organizações de defesa dos direitos humanos e direitos da mulher, o caso foi levado à Corte Interamericana de Direitos Humanos (CIDH), que condenou o Estado brasileiro por sua omissão e inércia em propiciar a responsabilização do autor, apesar de anos de denúncias efetuadas e do robusto acervo de provas.

As recomendações feitas pela Comissão (2001) não só iam no sentido de exigir o processamento penal das agressões sofridas por Maria da Penha, como também uma reforma ampla capaz de superar a tolerância estatal e o tratamento discriminatório no trato de situações de violência doméstica contra mulheres. Especificamente, foi recomendado o seguinte:

a) Medidas de capacitação e sensibilização dos funcionários judiciais e policiais especializados para que compreendam a importância de não tolerar a violência doméstica;

b) Simplificar os procedimentos judiciais penais a fim de que possa ser reduzido o tempo processual, sem afetar os direitos e garantias de devido processo;

c) $\mathrm{O}$ estabelecimento de formas alternativas às judiciais, rápidas e efetivas de solução de conflitos intrafamiliares, bem como de sensibilização com respeito à sua gravidade e às consequiências penais que gera;

d) Multiplicar o número de delegacias policiais especiais para a defesa dos direitos da mulher e dotá-las dos recursos especiais necessários à efetiva 
tramitação e investigação de todas as denúncias de violência doméstica, bem como prestar apoio ao Ministério Público na preparação de seus informes judiciais;

e) Incluir em seus planos pedagógicos unidades curriculares destinadas à compreensão da importância do respeito à mulher e a seus direitos reconhecidos na Convenção de Belém do Pará, bem como ao manejo dos conflitos intrafamiliares

Com as bases políticas consolidadas e com engajamento de vários setores da sociedade civil, uma das respostas estatais foi a promulgação da Lei 11.340/06, que visava o enfrentamento da violência doméstica e familiar contra mulheres no Brasil. Homenageando a peticionária, a lei ficou conhecida como Maria da Penha.

Sem dúvidas, a lei foi fruto do engajamento de vários setores da sociedade, especialmente do movimento feminista, que há muito tempo denuncia as bases patriarcais nas quais o Direito se constrói. Nesta linha, a referida legislação é aclamada, inclusive no âmbito internacional, por suas previsões inovadoras, dentre eles no sentido de: comprometer o poder público com a elaboração de políticas públicas de prevenção e enfrentamento à violência contra a mulher no contexto das relações domésticas e familiares (art. $3^{\circ}, \S 1^{\circ}$ ); definir várias formas de violência contra a mulher, como as de caráter físico (art $7^{\circ}, \mathrm{I}$ ), psicológico (art. $7^{\circ}$, II), sexual (art. $7^{\circ}$, III), patrimonial (art. $7^{\circ}$, IV) e moral (art. $7^{\circ}, \mathrm{V}$ ); determinar a criação de Juizados de Violência Doméstica e Familiar contra a Mulher (JVDFM) pela União, DF, Estados e territórios, que será competente para processar, julgar e executar as causas decorrentes da referida lei (art. 14), prever que os JVDFM contem com uma equipe de atendimento multidisciplinar, composta por profissionais especializados nas áreas psicossocial, jurídica e de saúde (art. 29) e prever a aplicação de medidas protetivas de urgência tanto ao agressor (art. 22) quanto à vítima (art. 23).

Dentre as principais mudanças que causam impactos processuais no âmbito penal, gostaria de focar em algumas: proibição da aplicação de penas de cesta básica ou outras de prestação pecuniária, bem como a 
substituição de pena que implique exclusivamente o pagamento de multa (art. 17); vedação da aplicação da Lei 9.099/95 aos crimes praticados com violência doméstica e familiar contra a mulher, independentemente da pena prevista (art. 41); aumento do rol das possibilidades de prisão preventiva, abarcando também as hipóteses de violência doméstica e familiar (art. 20)

A partir daqui, para melhor entendermos as mudanças trazidas pela Lei 11340/2006, devemos ter como base de apoio a Lei 9.099/1995. Essa última, popularmente conhecida como Lei dos Juizados Especiais, criou os Juizados Especiais Criminais (JECRIMs), órgãos da Justiça Ordinária com competência para processar, julgar e executar contravenções penais e crimes de menor potencial ofensivo, ou seja, crimes cuja pena máxima fossem menor ou igual a 2 (dois) anos. A necessidade de analisar conjuntamente os dois diplomas legais se explica porque, até a entrada em vigor da Lei Maria da Penha, os crimes cometidos no âmbito de violência doméstica eram processados, majoritariamente, pelos JECRIMs, seguindo o rito da Lei 9099/1995. Porém, a partir de 2006, essa possibilidade foi completamente afastada.

A centralidade dos JECRIMs no trato das agressões cometidas no âmbito de violência doméstica ocorria porque a maioria dos crimes cometidos contra a mulher são lesões corporais leves e ameaça (CAMPOS \& CARVALHO, 2011, p. 163-165), ou seja, crimes de menor potencial ofensivo que, ao se enquadram no conceito de baixa lesividade, atraem a aplicação da Lei 9099/1995.

O afastamento da aplicação do rito dos Juizados Especiais Criminais para o contexto de violência doméstica foi uma demanda daqueles que denunciavam seu caráter conciliatório, que propiciava a impunidade dos autores de delitos contra a mulher. Na verdade, a lei realmente foi fruto de uma pressão de alguns movimentos que defendiam uma política criminal mais despenalizadora, que vem para regulamentar comando constitucional (art. 98, inciso I, Constituição) no sentido de efetivar a criação de varas especiais para processamento e julgamento célere de demandas de menor 
gravidade, no âmbito civil e penal (CAMPOS \& CARVALHO, 2011, p. 147). Como resultante, temos a impossibilidade de utilizar instrumentos como a transação penal, suspensão condicional do processo e composição civil em casos onde, anteriormente, eram possíveis. Além disso, o flagrante passou a ser autorizado, o que leva a ser tangível a possibilidade de alguém ser preso por crime de lesão corporal leve ou ameaça. E mais: ainda é possível converter o flagrante delito em prisão preventiva, como já mencionamos anteriormente. Com isso, inequívoco o enrijecimento do tratamento penal que a Lei 11340 traz para a legislação (MEDEIROS \& MELLO, 2014, p. 11).

Um dos primeiros problemas que emergiram logo depois da edição da lei Maria da Penha é sobre qual seria a natureza da ação dos crimes de lesão corporal no âmbito de violência doméstica. Isso porque os crime de lesão corporal culposa e dolosa leve são condicionados à representação da vítima por conta da Lei 9099, mas, com a exclusão da aplicação desse diploma legal pelo o art 41 da Lei Maria da Penha, houve também a exclusão da ação penal pública condicionada à representação dentro do contexto doméstico. A questão foi levada do STF em sede de Controle de Constitucionalidade (ADI 4424), que por maioria dos votos proferiu uma decisão técnica, declarando que no âmbito da Maria da Penha, o crime de lesão corporal possui natureza de ação pública incondicionada. Na esteira, o STJ também editou a súmula 542: “A ação penal relativa ao crime de lesão corporal resultante de violência doméstica contra a mulher é pública incondicionada".

Isso significa que não é necessária a representação da vítima para que se inicie a persecução penal. Assim, a retratação da representação criminal restou limitadíssima, só sendo cabível nos termos do art 16, da Lei 11340, ou seja, antes do recebimento da denúncia, em uma audiência específica requerida pela vítima para tal fim.

Necessário relembrar que até essa mudança, muitas mulheres registravam a ocorrência na delegacia como forma de alcançar uma coação 
informal através da "mediação policial" e, depois, registravam tais ocorrências (MEDEIROS \& MELLO 2014). Foi justamente essa dinâmica e - a eventual coação que mulheres podem sofrer no curso do processo que o judiciário procurou evitar através da mudança da ação penal. Por outro lado, temos como resultado a limitação do exercício da autonomia da mulher em gerir seu próprio destino e suas relações privadas.

Ao adotar um braço penal, algumas políticas de atendimento à mulher e outros elementos elementos que permeiam os conflitos de gênero são colocados em segundo plano. Sobre as dinâmicas interseccionais, Jurema Werneck, em entrevista ao Jornal El País (2015), reforça que a Lei Maria da Penha, apesar de elogiável em diversos aspectos, "é parcial, na medida em que só cuida da violência na dimensão em que atinge a mulher branca". Segundo ela, a referida legislação seria "insuficiente para lidar com as demais violências que atingem a mulher negra e são decorrentes da maior vulnerabilidade a que ela está sujeita”.

Especulativamente, podemos levantar que atual literatura sobre violência doméstica também se demonstra insuficiente para alcançar a especificidade de mulheres negras em outros aspectos, na medida em que parte de uma construção de unidade familiar que, em regra, não é o padrão das famílias negras. Fica fora desta conta o fato de que famílias negras e de baixa renda são constituídas por redes amplas de relação, que trazem outras dinâmicas. Ao fazer uma leitura sobre mulheres negras, família e o amor, Beatriz Nascimento entende que:

\footnotetext{
"Via de regra, nas camadas mais baixas da população cabe à mulher negra o verdadeiro eixo econômico onde gira a família negra. Essa família, grosso modo, não obedece aos padrões patriarcais, muito menos os padrões modernos de constituição nuclear. São da família todos aqueles (filhos, maridos, parentes) que vivem em dificuldades de extrema pobreza" (NASCIMENTO, 2006, p. 128)
}

Como este entendimento pode reorientar a maneira pela qual pensamos a Lei Maria da Penha e as medidas protetivas de urgência? Como (re)pensar o afastamento do lar, por exemplo, quando o núcleo familiar é constituído pelo "quintal" de casa? Em bom pretuguês,como (re)pensar 
nosso ideal de violência doméstica se não há a dinâmica de família baseada apenas na mulher, o provedor e os filhos, já que a mulher negra sempre trabalhou e o núcleo familiar inclui outros parentes? 


\section{Capítulo 4. Discursos Negros situando Feminismos e Criminologias}

A Lei Maria da Penha tem estado no centro do debate de feministas e criminólogos críticos desde sua promulgação. A intervenção estatal e a emergência de um assunto a ser debatido na esfera pública constituem as grandes vitórias para o movimento feminista, enquanto significam um certo "pesadelo" para movimentos abolicionistas, numa dinâmica onde ideais emancipatórios colidem com mecanismos de repressão e controle social que ignoram hierarquias sociais baseadas em raça e classe (FERRARO, 1996, p. 77). Essa tensão foi muito bem percebida por Baratta (1999, p. 43), indicando que "a introdução do paradigma da reação social em criminologia foi contemporânea ao aparecimento do feminismo, mas, infelizmente, estes pouco usufruíram um do outro".

Assim, em que pese seus esforços emancipatórios, cada um do um lugar, quando o tema é violência contra mulheres testemunhamos um fogo cruzado. De um lado, feministas demandam um maior rigor no trato de violências de gênero, inclusive com maior rigor penal. De outro, criminólogos em geral se recusam a incorporar uma análise com recorte de gênero, sendo silentes às reflexões sobre dominação masculina. O resultado deste fogo cruzado é um só: a marginalização, em ambos os campos, das experiências de mulheres negras.

Por isso, proponho uma análise da violência doméstica a partir de um outro lugar. Esse lugar passa, necessariamente, por reflexões que levem em conta as dimensões estruturais da violência de gênero, além da adoção de uma lente que mobilize discussões sobre o papel do Estado Penal. Assim, a partir da criminologia crítica comprometida, do feminismo negro e das resistências pragmáticas de mulheres em situação de violência, algumas questões referentes à Lei Maria da Penha ficam latentes. De que forma o racismo institucional, as imagens controladoras e estereótipos direcionadas à mulheres negras, a violência policial em favelas e subúrbios, o genocídio 
do povo negro e um racista sistema de justiça criminal, dentre tantas outras variáveis, podem alterar a forma pela qual entendemos e lutamos contra violência de gênero? De que forma essas disputas se colocam no acesso ou resistência de mulheres à Lei Maria da Penha? A militarização do Rio de Janeiro traz, para mulheres negras e periféricas, algum impacto na busca da polícia e do judiciário diante de uma situação de violência doméstica? Como acessar o Estado quando é ele mesmo o maior violador dos direitos? Propor uma reflexão considerando todos essas variáveis, obviamente, foge dos objetivos de um trabalho monográfico. Apesar de não haver resposta pronta, quero refletir sobre alguns pontos, que vão ao encontro das problematizações levantadas por Ana Flauzina:

"Afinal, pode-se arguir, o que uma leitura da Lei Maria da Penha, focada na punição dos agressores reverbera? Há uma possível mediação do racismo operando nesse tipo de postura política? O que sinalizam as posturas das mulheres em situação de violência doméstica a esse tipo de perspectiva? Quão próximas estão, em suma, as investidas da militância e as demandas da resistência? (Flauzina, 2015, p. 132)

\subsection{Lendo as estruturas: o feminismo negro}

"O feminismo envolve muito mais do que a igualdade de gênero; e envolve muito mais do que gênero. Ele deve envolver uma consciência do capitalismo - quer dizer, o feminismo com o qual eu me relaciono, existem múltiplos feminismos, certo? Ele envolve uma consciência do capitalismo, racismo, colonialismo, póscolonialismo e muitos mais gêneros que podemos imaginar e mais sexualidades que pensamos que podemos nomear [...] A abolição da prisão também deve abranger a abolição da opressão de gênero. Esse processo revela a violência epistêmica, a violência inerente à construção binária de gênero na sociedade em geral. Então, colocar o feminismo dentro de um quadro abolicionista e vice-versa, trazendo a abolição a partir de um quadro feminista, significa que levamos a sério a velha frase feminista "o pessoal é político". (DAVIS, 2013, 49-53m, tradução nossa) 
A frase de Angela Davis destacada acima prende minha atenção por muitos motivos. Primeiro porque coloca na ordem do dia o impacto e o poder de transformação a partir da mobilização de mulheres negras. Depois, abre a reflexão para pensarmos os caminhos de resistência que trilhamos até aqui, que diz respeito não a um evento pontual, mas estrutural: historicamente, mulheres negras lutam em vários frontes, contra várias formas de opressão, numa dinâmica em que violência de gênero e violência institucionais não são distintos, mas face da mesma moeda.

Em uma lógica patriarcal, a expressão “em briga de marido e mulher ninguém mete a colher" parece evidenciar a dimensão eminentemente privada na qual as violências ocorridas dentro dos lares historicamente foram - e deveriam continuar — sendo tratadas. Contudo, o movimento feminista, há tempos vem chamando atenção à falsa dicotomia do "público x privado" e, através das articulações em torno da Maria da Penha foi vitorioso ao trazer a questão para o ambiente público.

Um outro dado que precisa ser levado em conta, pois trazer a discussão para o âmbito público, por si só não é suficiente. Se o pessoal é político, as análises de violência de gênero precisam ser atravessadas pelas análises de outras formas de opressão — racismo, capitalismo, colonialidade etc. - , promovendo, assim, seu devido enfrentamento. Do contrário, como a frase de Davis indica, não será possível acessar as especificidades de outros corpos. Ao refletir sobre violência sexual a qual mulheres constantemente estão submetidas, a autora se pergunta:

\footnotetext{
“Os homens estupram porque são homens ou eles são socializados pela opressão econômica, social e política - como também pelo nível de violência social no país em questão - a cometer violência sexual contra mulheres? Eu quero sugerir que estupro se relaciona diretamente com todas as estruturas de poder em uma dada sociedade. Essa relação não é apenas mecânica, mas envolve uma complexa estrutura refletindo a complexa interconectividade de opressões de raça, gênero e classe que caracteriza a sociedade. Se não tentamos entender como a natureza da violência sexual se relaciona com raça, classe e poder e violência governamental, não podemos nem começar a desenvolver estratégias que irão permitir eventualmente purgar da nossa sociedade a opressão do estupro." (DAVIS, 1985, p. 7-8, tradução nossa)
} 
Porém, essa perspectiva que possibilita enxergar em que medida a prática de violência contra a mulher é informada por estruturas de poder em nossa sociedade não está na ordem do dia. Inclusive a análise de violência de gênero foi questionada por haver se limitado a uma dimensão que levava em conta apenas a esfera doméstica e intrafamiliar (CURIEL, 2007).

Trazer trabalhos de mulheres negras que denunciam violências estruturais em se faz necessário porque parecem indicar alguns perigos de defender o enfrentamento do problema doméstico a partir do aparato penal. Isso porque, como argumentado por Donna Coker e Macquoid (2015), tal abordagem além de deixar em segundo plano a busca por soluções que possibilitem o rompimento com o ciclo de violência, inevitavelmente estreitam os caminhos para compreender e combater a violência contra as mulheres em dimensões estruturais. $\mathrm{O}$ direito penal, por excelência, reduz a complexidade e a extensão da violência a um âmbito interpessoal, individualista, ou seja, o autor agride a vítima e nada mais é levado em consideração. Tal dinâmica torna invisível as maneiras pelas quais as desigualdades estruturais - muitas das quais são produtos da violência estatal - tornam algumas mulheres e homens mais vulneráveis à violência. Em outras palavras, a violência perpetrada pelo Estado é escondida quando a "violência contra as mulheres" é extensiva somente à esfera doméstica, como é o caso da Maria da Penha.

Vivendo na base da pirâmide social, a experiência das mulheres negras é diretamente atravessada por um contexto de feminização da pobreza, genocídio, brutalidade policial, solidão, racismo institucional e violências simbólicas. Para dar conta destas muitas dimensões de opressão é necessário um movimento que intervenha tanto nas violências estatais e estruturais como nas interpessoais, especificamente no âmbito da violência doméstica. Em outras palavras, para as mulheres negras, seria inócuo um movimento que pretenda refletir sobre violência doméstica mas que seja cego às dinâmicas estruturais, onde o racismo é o principal norteador. Assim, para ser efetivamente potente, os movimentos ativistas que 
denunciam a violência estatal, seja na forma de encarceramento em massa seja na forma de brutalidade policial, devem trabalhar próximo aos movimentos que endereçam as violência sexual e doméstica. A frase de Angela Davis que abre esse capítulo também dá centralidade a uma questão pouco discutida nos debates feministas: o quanto o sistema penal e a prisão enquanto instituição reforçam a exploração de mulheres.

\title{
4.2 Lendo o sistema de justiça criminal: a Criminologia
}

Loic Wacquant (2001) levanta tese de que o estado previdenciário foi substituído pelo Estado Penal, e os números gritantes da era do encarceramento em massa que vivemos, por si só, confirmaria este argumento (BATISTA, 2009). Nesse contexto, vivemos um momento de expansão do sistema e controle penal que sempre inclui novas e variadas demandas:

\begin{abstract}
"Uma demanda criminalizadora contra a criminalidade do colarinho branco (até agora só punimos os pobres, agora vamos punir os ricos), uma demanda dos novos movimentos sociais (aqui é que eu vou inserir o feminismo) e, por fim, uma demanda radicalmente criminalizadora, operacionalizada pelos chamados Movimentos de "Lei e Ordem" que encontram na mídia o seu mais poderoso instrumento de difusão" (ANDRADE, 1997)
\end{abstract}

O Estado Penal tem sido analisado por seu caráter destrutivo, controlador e operacionalizado para promover extermínio da zona do não ser. Historicamente, a carne mais barata do mercado se vê marcada por duas opções: morrer nas mãos da polícia ou sucumbir atrás das grades do cárcere. Via de regra, as mulheres negras são vigilantes em relação às posturas punitivistas ${ }^{15}$ porque sabem que confiar no braço penal do Estado é

\footnotetext{
${ }^{15}$ Em outro contexto, nos Estados Unidos, Angela Davis (2016, p. 178) nos mostra como as mulheres negras nos Estados Unidos, desde o pós abolição, "têm estado visivelmente ausente das fileiras do movimento antiestupro", apesar deste crime ter sido uma arma utilizada como forma de controle das mulheres escravizadas e, no pós abolição, também ter sido instrumentalizado por grupos terroristas como a KuKluxKlan. Esta resistência pode ser explicada porque o movimento se mostrava essencialmente punitivista e idealizado dentro do bojo de um processo de criação do
} 
alimentar esta dinâmica genocida, da qual também são vítimas preferenciais.

Buscando, porém, maior proteção e segurança para as mulheres, os movimentos feministas desenvolveram práticas que colaboram com o Estado para aumentar intervenções penais, defendendo "um uso alternativo do poder punitivo como estratégia emancipadora das opressões" (BATISTA, 2009). Porém, do ponto de vista das vítimas, existe uma uma discrepância entre os anseios das vítimas e a militância hegemônica feminista no sentido de um maior rigor no trato de violências de gênero, lançando mão inclusive do braço penal do Estado, evidenciando que:

"[...] a grande maioria das mulheres que fazem uso dos Juizados Especiais (cerca de $80 \%$ ) não quer que o seu agressor - com quem ela mantém ou manteve uma relação doméstica, familiar ou íntima de afeto - seja condenado a uma pena privativa de liberdade. Das mulheres entrevistadas, apenas $20 \%$ manifestaram o pensamento de que a melhor solução seria a de aplicar pena e prender o agressor. Os outros $80 \%$ acreditam que a melhor solução não envolve uma pena privativa de liberdade" (IPEA, 2015, p. 77)

O feminismo hegemônico parecem ainda não ter refletido sobre como o Estado Penal é um sistema que cria, motiva e reforça o estupro e violência contra as mulheres tanto dentro como fora das prisões.

\footnotetext{
"Antes do surgimento da prisão como principal forma de punição pública, era certo que os infratores da lei estariam sujeitos a penas corporais e capitais. O que geralmente não é reconhecido é a conexão entre o castigo corporal infligido pelo Estado e o castigo físico contra as mulheres ocorridos em espaços domésticos. Esta forma de disciplina do corpo continuou a ser rotineiramente direcionada às mulheres no contexto de relacionamentos íntimos, mas é raramente entendido como relacionada à punição estatal” (DAVIS, 2003, p. 68, tradução nossa)
}

As mulheres encarceradas, negras em sua maioria, ficam de fora da existente literatura sobre violência contra a mulher. Neste sentido, o trabalho de Carla Adriana da Silva Santos (2014) nos ajuda a repensar a aplicação da Lei Maria da Penha para mulheres que já vivenciaram a mão sancionadora do Estado Penal. Segundo ela, um importante passo no

mito do estuprador negro, que foi elaborado com o objetivo de exterminar o povo negro através dos linchamentos. 
enfrentamento do sexismo e racismo institucionais seria enxergar as mulheres encarceradas como vítimas de violências contra a mulher, nas celas enquanto ambiente doméstico, cometidas por outras mulheres e agentes penitenciários. Na atual gramática da violência doméstica não é analisado, por exemplo, em que medida o fato de ter antecedentes criminais fragiliza a credibilidade de uma eventual denúncia de violência doméstica. Assim,

"Há mulheres privadas de liberdade meramente punidas pela manutenção de ciclos de violência. Nas prerrogativas raciais dos processos penais, seus antecedentes criminais já fragilizam largamente a credibilidade para denúncias de violências doméstica, psicológica, patrimonial e de danos morais perpetradas por companheiros e filhos. Em especial, as mulheres negras dentro do cárcere, são personagens antes problematizadas nas teorizações do feminismo negro como público que deve cada vez mais criar condições psicológicas para denunciar homens violentos, mesmo que fiquem sem nada, pois o racismo condicionou as negras a uma subjetividade capaz de aceitar pouco e ainda se culpar pela opressão experimentada" (SANTOS, 2014, p. 148).

Em diversos artigos de autoria conjunta entre Marília Montenegro Mello e Carolina Salazar Medeiros (2014) há uma perspectiva que considero essencial, ainda pouco explorada pela academia. As autoras se debruçam sobre os impactos da Lei Maria da Penha no encarceramento masculino e seus efeitos colaterais sobre as mulheres em situação de violência doméstica. A hipótese levantada é que ao apostar no incremento punitivo, a legislação acaba por trazer diversas consequências negativas para as mulheres.

Para além disso, podemos dialogar com a frase de Angela Davis que abre esse capítulo, no sentido de entender que esses efeitos gerados pelo encarceramento masculino e pelo uso do braço penal não são apenas colaterais para as mulheres, mas eles estruturam a existência do poder punitivo. Com isso damos centralidade a uma questão esquecida nos debates feministas: o sistema penal e a prisão enquanto instituição reforçam a exploração de mulheres. Talvez a razão desse "esquecimento" seja pelo fato de que é no lombo das pretas que esta dinâmica recai rotineiramente. 
Ana Flauzina (2016a; 2016b) nos contempla nesse sentido ao argumentar que o sistema de justiça criminal se apoia, fundamentalmente, na vulnerabilização e exploração de mulheres em todos os níveis de sua intervenção. Em outras palavras, o sistema penal não só traz efeitos colaterais para as mulheres, mas é tornado viável a partir da exploração de mulheres negras, mesmo quando estamos falando de criminalização de homens. São elas que suportam, de forma desproporcional, os encargos econômicos, sociais e psicológicos que o encarceramento gera. Nesse contexto, as mulheres se tornam as responsáveis por sustentar a família e também o apenado dentro da prisão, seus corpos se tornam moeda de troca de cunho sexual que servem para "acalmar" os apenados durante as visitas conjugais, sua dignidade é estilhaçada por conta das revistas vexatórias e, ainda, se tornam os motores que impulsiona o sistema de Justiça, ao acompanhar os trâmites processuais de seus companheiros do lado de fora, nas defensorias e tribunais. Além disso, sofrem a brutal estigmatização e rejeição tal qual seus companheiros, filhos, netos, sobrinhos encarcerados.

Como demonstrado na seção anterior, a Lei Maria da Penha traz um recrudescimento punitivo no trato da violência doméstica, ainda que não gere efeitos significativos na taxa de encarceramento no Brasil, como demonstra importante pesquisa de Adriana Vidal de Oliveira e Rodrigo de Souza Costa (2014). Nesse sentido, segundo dados do Sistema Integrado de Informações Penitenciárias (InfoPen), no ano de 2016, o percentual da população carcerária que respondia por violência doméstica (art 129, §1 ${ }^{\circ}$, Código Penal) era de 1\%, totalizando 4848 pessoas, que se encontravam presos em virtude de cumprimento de sentença condenatória ou por força de prisão preventiva ${ }^{16}$.

\footnotetext{
${ }^{16}$ Podemos olhar os dados de encarceramento por outra perspectiva, chamando atenção ao aprisionamento de outra forma. De acordo com pesquisa realizada na Vara de Violência Doméstica e Familiar contra a mulher do Recife (MEDEIROS \& MELLO, 2014, p. 146-147), apesar de 99,5\% das infrações processadas na Vara dizerem respeito a crimes de menor potencial ofensivo - ameaça (55\%), lesões corporais leves (23\%) e crimes contra a honra (16\%) - em $17 \%$ dos casos analisados o réu esteve preso durante todo ou parte do processo. Dos que ficaram preso durante parte do processo, $38 \%$ deles teve sentença condenatória, mas na maioria dos casos $(67 \%)$ não houve previsão de pena privativa de liberdade. Ou seja, na maioria dos casos em que o
} 
Aqui, porém, gostaria de dar dimensão a um outro dado: o punitivismo enquanto direito penal simbólico, que pode ser entendida como:

“[...] a inflação de normas penais criminalizando campos da vida social que antes não eram regulados por sanções penais. Por meio do uso do direito penal, como resposta para todos os tipos de conflitos e problemas sociais frente às demandas por segurança e penalização na sociedade atual, e sem qualquer relação direta com a verificação da eficácia instrumental como meio de prevenção ao delito" (SILVEIRA CAMPOS, 2010, p.103).

Ou seja, ao entender que a Lei Maria da Penha traz uma dimensão "punitivista", não necessariamente estamos associando punitivismo com encarceramento. Na verdade, estamos chamamos atenção para o paradoxo de ter o direito penal como fonte primária de solução de conflitos, apostando em seus efeitos simbólicos e pedagógicos. Inegável o fato de que vivemos em uma sociedade que deposita as esperanças no sistema punitivo. Nosso ideal de justiça é sempre formatado pela ideia de prisão, é aquilo que está calcado tanto no imaginário popular como no da militância quando se trata de "fazer justiça". E, especialmente em tempos de "lei e ordem", o direito penal simbólico é algo extremamente atrativo e com apreço, inclusive, de políticos, que gostam de se promover por terem defendido penas mais duras e o combate ao crime (COKER, 2001, p. 803).

É esse ideal desenfreado por punição — um "gosto de sangue na boca" dos movimentos sociais - que explica o fato de, por exemplo, termos abandonado o modelo de aplicação da suspensão condicional do processo no trato da violência doméstica. Dados ${ }^{17}$ demonstram que uma intervenção interdisciplinar realizada a partir de um acompanhamento rigoroso pode resultados mais satisfatório, inclusive em relação à reincidência (FLAUZINA, 2016).

\footnotetext{
acusado ficou preso durante o processo, a pena final não confirmou a necessidade de pena privativa de liberdade.

17 Ver: BARRETO, Fabiana Costa de Oliveira. Redução de casos de violência doméstica e familiar contra a mulher na circunscrição judiciária do Paranoá: números, princípios e razões. Revista Brasileira de Segurança Pública. São Paulo. v.7, n.2, 200-220 Ago/Set, 2013, p.217.
} 
O que estamos falando, portanto, é que a dimensão do direito simbólico traz efeitos consideráveis para quem, desde sempre, lida com as muitas facetas do estado penal. O discurso punitivista assume uma forma totalizante, como função não declarada de manter hierarquias raciais, de classe e de gênero. Assim sendo, não é possível mobilizá-lo até onde nos convém, especialmente no cenário atual de encarceramento em massa. Analisando o percentual de crescimento do encarceramento de mulheres nos últimos anos, vemos que mulheres negras têm sido os corpos preferenciais do punitivismo, em um sistema que fomenta as condições que colocam esse grupo em um patamar de maior vulnerabilidade social e, consequentemente, as pune por essa mesma vulnerabilidade (CRENSHAW, 2012). Sobre a necessidade de entender como gênero estrutura o sistema punitivo, Angela Davis discorre:

\footnotetext{
"Refletir sobre questões específicas de prisões femininas é de vital importância, mas é igualmente importante mudar a maneira como pensamos o sistema prisional como um todo. Certamente, as práticas que envolvem o aprisionamento de mulheres são genderizados, mas assim também são as práticas que envolvem a prisão para homens. Assumir que as instituições para homens constituem a norma e as instituições femininas são marginais é, em certo sentido, participar da própria normalização das prisões que uma abordagem abolicionista procura contestar. Assim, o título deste capítulo não é "Mulheres e o Sistema Prisional" mas, sim, "Como o Gênero Estrutura o Sistema Prisional". Além disso, acadêmicos e ativistas que estão envolvidos em projetos feministas não devem considerar a estrutura de punição estatal como marginal ao seu trabalho. Pesquisadores progressistas e organizações estratégicas devem reconhecer que o caráter profundamente genderizado de punição tanto reflete e fortalece ainda mais a estrutura de gênero da sociedade como um todo" (DAVIS, 2003, p. 61 - tradução nossa)
}

Apesar de mulheres negras ocuparem grande parte daquilo que se denominou sistema prisional-industrial, esse grupo sofre uma dupla invisibilidade: de um lado, os discursos sobre encarceramento em massa, controle e punição são frequentemente mobilizados na perspectiva da masculinidade e, de outro, mesmo as análises mais sensíveis às dinâmicas raciais ou de gênero também são silentes quanto à presença de mulheres negras no sistema (CRENSHAW, 2012). 
A maior estratégia utilizada pelo movimento feminista no sentido de defender a criminalização da violência contra a mulher não trará um fim à violência doméstica e feminicídios, assim como o encarceramento não colocou um fim ao "crime" em geral (DAVIS, 2000, p. 5). Isso porque o processo penal, ao atuar numa lógica de expropriação do conflito entre autor e vítima, acaba por ignorar as origens deste, o que reduz a complexidade da situação por não contemplar suas peculiaridades e múltiplas facetas. A violência de gênero no contexto doméstico envolve relações pessoais, íntimas e familiares, fazendo com que o conflito seja mais complexo e particular (IPEA, 2015, p. 20).

O direito penal não é capaz de traduzir as violências sofridas que não são marcadas visivelmente na carne (PRANDO, 2016). Na verdade, essa tradução segue uma ritualística processual, fria e cartesiana, que tem muito pouco a oferecer, na medida em que suas respostas se encaixam em um modelo uniformizado, de escala industrial, capaz de apresentar como única reação à situação conflituosa uma resposta punitiva, através da pena (IPEA, 2015, p. 20; MEDEIROS \& MELLO, 2014, p. 50), Nesse sentido, como coloca Alessandro Baratta, no processo “os conflitos não podem ser resolvidos, senão unicamente reprimidos".

As mulheres reivindicam escuta e atenção, ou seja, "escuta de suas necessidades urgentes; de sua narrativa das agressões sofridas; respeito pela forma como pôde resistir [...] e pela sua autonomia e vontade na condução e o desfecho do caso" (FLAUZINA, 2015, p. 133). Em outras palavras, as vítimas buscam proteção e formas efetivas e concretas para a resolução dos conflitos domésticos, que não necessariamente passa pela punição do agressor (MEDEIROS \& MELLO, 2014). 


\subsection{De que vítima estamos falando? O encontro do direito penal com os estereótipos de gênero}

O poder punitivo espera um determinado tipo de vítima ${ }^{18}$. A própria dinâmica teatral que o processo penal assume ao de ter, de um lado, o culpado e, de outro, a vítima, que é totalmente expropriada do conflito e substituída pelo Estado no papel do Ministério Público (PRANDO, 2016), sinaliza essa lógica. Nesses termos, a vítima assume o papel da passividade, da invisibilização, da mudez, alguém que vê seus interesses alijados ante um processo penal que não está preocupado com seus anseios e muito menos com uma dinâmica capaz de evitar a vitimização secundária.

Parece oportuno retomar algumas das reflexões que apareceram ao longo do trabalho: quais são os corpos que podem ver sua voz reverberadas enquanto ação política? Quais são os corpos que podem ter suas dores mensuradas e seu papel de vítima devidamente reconhecido? Quais são os corpos que podem vivenciar uma situação de violência que efetivamente é lida enquanto tal, sem naturalização? Importante retomar também algo que elucidamos logo nas primeiras linhas do primeiro capítulo: existem vítimas e vítimas. E, historicamente, corpos negros são impedidos de reivindicar qualquer tipo de vitimização.

Como denunciado por Ana Flauzina e Felipe Freitas (2017), o modo pela qual as relações raciais são construídas no Brasil e a plena operação do maquinário do genocídio tem como resultado específico a profunda indiferença ao sofrimento gerado em corpos negros, o que impede a reivindicação da vitimização para esse contingente social. Há, portanto, um paradoxo em curso: apesar de negros serem inscritos nas fileiras das violências estatais e interpessoais enquanto corpos rotineiramente vitimizados, como demonstrado por pesquisas ao longo do capítulo 2, o reconhecimento desse papel é uma marca de privilégio. Privilégio esse balizado a partir dos termos da branquitude.

\footnotetext{
${ }^{18}$ Para uma discussão aprofundada sobre vitimologia no Brasil contemporâneo, Ver: PEIXOTO, Maria Gabriela Viana (2016)
} 
Por excelência, o processo em que podemos ver o perfeito confisco da condição de vítima são a partir dos encontros fatais entre as agências policiais, que através dos autos de resistência operacionalizam um verdadeiro fazer viver e deixar morrer Foucaultiano nas favelas e subúrbios brasileiros. Para a zona do não ser, não sobra nada, nem a memória pública, já que esta também é vilipendiada na tentativa de dar algum racionalidade àquilo que é irracional: o genocídio do povo negro.

Além dessa dimensão pública especialmente brutalizada, também podemos ver o confisco da condição de vítima no contexto de violência doméstica, já que as investidas do sistema de justiça criminal se traduz de forma diferente nos diferentes corpos. O simbolismo do controle punitivo reservou às mulheres brancas, o espaço de vitimização e, não por acaso, suas imagens são utilizadas pelo imaginário punitivista para alavancar coesão social na busca do enrijecimento penal (FLAUZINA, 2016). Lembremos, por exemplo, que a Lei de Crimes Hediondos foi aprovada após o clamor social levantado pela trágica morte de Daniela Perez, filha da diretora Glória Perez. A Lei 8.038/90 inaugurou uma nova fase punitivista no direito penal brasileiro, aumentando as penas dos delitos classificados como hediondos, aumentando o prazo para livramento condicional e vedando possibilidade a progressão de regime, comutação e indulto aos crimes dispostos (CARVALHO, 2010).

Como identifica Vera Andrade (2005, p. 85), a vítima do sistema penal é construída nos mesmos termos da representação do estereótipo do gênero feminino, caracterizada principalmente pela passividade, fragilidade, impotência e domesticação. Nesses termos, portanto, a imagem mobilizada da vítima de violência doméstica é aquela que tem a branquitude como parâmetro.

Em relação às mulheres negras, por outro lado, como demonstrado anteriormente, a destituição de sua humanidade e da agência vem em outros termos. Mulheres negras são criadoras de caso, barraqueiras, estressadas, hipersexualizadas, tão fortes que são vistas como o burro de carga da 
sociedade brasileira. Dessa forma, histórias de mulheres que não seguem essa linha e denúncias que não correspondem ao que é esperado de uma vítima são invisibilizadas.

Outro ponto que merece reflexão é sobre se e em que medida a representação estereotipada das mulheres negras podem afetar a busca pela efetividade da Lei Maria da Penha no judiciário. Especialmente a partir de uma construção social que tem o corpo negro como hipersexualizado, que pode suportar dor e, por outro lado, uma construção institucional de sistema de justiça que questiona o comportamento da vítima na condução dos processos de violência, parece interessante questionar em que medida o racismo institucional media essa relação, levantando dúvidas sobre as narrativas. Ainda não temos literatura suficiente que discuta como o racismo institucional pode impactar a decisão de mulheres em acionar a Lei Maria da Penha - mais uma vez, os silêncios dizem muita coisa. 


\section{CONCLUSÃO}

O capítulo de conclusão sempre nos ajuda a reiterar aquilo que a pesquisa potencializou. Também nos ajuda a organizar o pensamento, reconhecer as limitações e começar a trilhar um caminho para futuras indagações. Neste trabalho, andamos muito. A partir de uma apropriação das potencialidades críticas do feminismo negro e de uma criminologia comprometida com as agendas dos movimentos negros, observamos os contornos hegemônicos que a atual produção acadêmica sobre violência doméstica apresenta. Dessa forma, ficou evidente o quanto é urgente mobilizar as categorias de raça, gênero, classe, sexualidade e colonialidade conjuntamente, na medida em que são causa e efeito umas das outros. A disputa, portanto, não é meramente identitária, como alguns insistem em dizer. A disputa é por repactuar os termos do debate, chamando atenção às estruturas de poder que não só nos constituem, mas estruturam nossas relações intersubjetivas e institucionais.

Com isso, devemos apostar em análises que transcendam a falsa igualdade material dos sujeitos e percebam a inviabilidade do segmento negro em nossa sociedade, especialmente de mulheres negras. Somos minoria absoluta nas universidades, na política, nos espaços de poder. Por outro lado, temos lugar certeiro na base da pirâmide social, nas crescentes taxas de encarceramento e nas cifras dos encontros violentos, muitas vezes fatais, seja com a polícia, seja dentro de casa.

Para melhor analisar o contexto social no qual mulheres negras em situação de violência doméstica estão inseridas, parece interessante trazer para a conversa tanto o aporte sobre violência de gênero, mobilizados pelo feminismo, como as análises das diversas violências institucionais, trazidas pela criminologia crítica. Assim, a violência doméstica poderá ser vista não como um fenômeno que diz respeito tão somente ao gênero enquanto relação de poder. Adotamos uma lente decolonial justamente para evitar 
isso: não há como mobilizar gênero fechando os olhos para as intersecções e imbricações com estruturas racializadas, cishetenormativas e capitalistas.

As reflexões sobre violência doméstica não podem mais ser centralizadas na imagem da "vítima" essencializada, ou seja, a mulher branca, heterossexual, de classe média, que nunca teve experiência com brutalidade policial ou sistema prisional e que não sofre de racismo institucional. Da mesma forma, a criminologia deve racializar seu debate, indo além de uma análise superficial sobre o "cliente" do sistema penal, ou seja, o homem negro heterossexual, que não necessariamente experimentou violência de gênero.

Ao longo do trabalho, colocamos algumas provocações. Respondemos algumas, mas nem todas. Espero, um dia, ver a continuidade desse trabalho. Se não por mim, em algum momento da minha vida acadêmica que pretendo seguir, por outras vozes. Pegando emprestado o conceito de Conceição Evaristo marcado no título da monografia, mobilizei o meu "escrever" e partilhei o meu "viver" num esforço de contribuir, ainda que minimamente, para uma nova forma de enfrentamento contra a violência de gênero. Atenta ao fato de que "as ferramentas do mestre nunca vão desmantelar a casa-grande" (LORDE, 1979), quis começar por outro lugar, quis partilhar minhas escrevivências - que, como nos alerta Conceição Evaristo, não podem ser lidas com histórias para 'ninar os da casa grande' e sim para incomodá-los em seus sonos injustos. Sigamos incomodando. 


\section{Referências}

ALBUQUERQUE. Mariana Imbelloni Braga. Lendo Silêncios: a interseccionalidade de violências nas entrelinhas das estatísticas. XIII Seminário de Iniciação Científica da PUC - RIO. Disponível em: <https://bit.ly/2RNuVPj>, 2015.

ANDRADE, Vera Regina Pereira de. Criminologia e Feminismo: da mulher como vítima à mulher sujeito da construção da cidadania. Revista Sequência. Santa Catarina, Florianópolis: EdUFSC, v. 18, n. 35, p. 42-49, 1997.

ANDRADE, Vera Regina Pereira de. A soberania patriarcal. O sistema de justiça criminal no tratamento da violência sexual contra a mulher. Revista Sequuência - Estudos Jurídicos e Políticos, Programa de Pós-Graduação Stricto Sensu em Direito da UFSC, Florianópolis, v. 26, n. 50, 2005.

AKOTIRENE, Carla. E elas, não são mulheres?. Brado Negro. Disponível em: <http://bradonegro.com/produtos.asp?PagAtual=40\&TipoID=4>.

ALMEIDA, Tânia Mara Campos de; PEREIRA, Bruna Cristina Jaquetto. Violência doméstica e familiar contra mulheres pretas e pardas no Brasil: reflexões pela ótica dos estudos feministas latino-americanos. Crítica $e$ Sociedade: revista de cultura política, v. 2, n. 2, Dossiê: Cultura e Política, p. 42-63, dez. 2012

ASANTE, K. Afrocentricidade: notas sobre uma posição disciplinar. In: NASCIMENTO, E. L. (Org.). Afrocentricidade: uma abordagem epistemológica inovadora. São Paulo: Selo Negro, 2009. p. 93-110.

BARATTA, Alessandro. "Da questão criminal à questão humana". In: CAMPOS, Carmen Hein (org.). Criminologia e Feminismo. Porto Alegre: Sulina, 1999.

BATISTA, Nilo. "Só Carolina não viu" - A violência doméstica e políticas criminais no Brasil. In MELLO, Adriana Ramos de (org.) Comentários à Lei de Violência Doméstica e Familiar contra a Mulher. 2 ed., Rio de Janeiro, 2009

BENTO, Maria Aparecida S. Pactos narcísicos no racismo: branquitude e poder nas organizações empresariais e no poder público. Tese de Doutorado. Instituto de Psicologia Social, Universidade de São Paulo, 2002. 
BERNARDES, M. N.; ALBUQUERQUE, M. I. B. Violências Interseccionais silenciadas em Medidas Protetivas de Urgência. Revista Direito e Práxis, v. 7, p. 715-740, 2016.

BORGES, Rosane. Sueli Carneiro. Retratos do Brasil Negro. Coordenada por Vera Lúcia Benedito. São Paulo: Selo Negro, 2009.

CALAZANS, Márcia; CAPPI, Riccardo; PIZZA, Evandro; PRANDO, Camila;

Criminologia Crítica e Questão Racial. Cadernos do CEAS, Salvador, n. 238, p. 450-463, 2016.

CALDWELL, Kia Lilly. Fronteiras da diferença: raça e mulher no Brasil. Revista Estudos Feministas, v. 8, n. 2, p. 91-108, 2000.

CAMPOS, Carmen Hein de; CARVALHO, Salo. Tensões atuais entre a criminologia feminista e a criminologia crítica: a experiência brasileira. In: CAMPOS, Carmen Hein de (Org.). Lei Maria da Penha Comentada em uma perspectiva jurídico-feminista. Rio de Janeiro: Lumen Juris, 2011, p.143-172.

CARNEIRO, Sueli. Enegrecer o feminismo: a situação da mulher negra na América Latina a partir de uma perspectiva de gênero. In: Racismos Contemporâneos, Rio de Janeiro: Takano Editores, 2003.

CARNEIRO, Sueli. A Construção do Outro como Não-Ser como Fundamento do Ser. Tese de Doutorado. Programa de Pós-Graduação em Educação da Universidade de São Paulo, 2005.

CARVALHO, Salo. Substitutivos penais na era do grande encarceramento. In: Criminologia e sistema jurídico-penais contemporâneo II. Org. Ruth Maria Chittó Gauer.p.146-171, 2010.

COKER, Donna. Crime Control and Feminist Law Reform in Domestic Violence Law: A Critical Review, 4 Bu . Crim. L. Rev. 801, 2001.

COKER, Donna; MACQUOID, Ahjané D. Why Opposing HyperIncarceration Should Be Central to the Work of the Anti-Domestic Violence Movement, 5 U. Miami Race \& Soc. Just. L. Rev. 585, 2015

COLLINS, Patricia Hill. Black Feminist Thought: Knowledge, Consciousness, and the Politics of Empowerment. New York, Routledge, Chapman and Hall, 1990.

COMISSÃO Interamericana de Direitos Humanos. Organização dos Estados Americanos. Relatório Anual 2000. Relatório no 54 01, caso 
12.051, Maria da Penha Maia Fernandes, Brasil, 4 de abril de 2001. Disponível em <https://bit.ly/2PUbEP9 $>$.

CONCEIÇÃO, Í. A. ; PRUDENTE, E. A. J. . Justiça Racial e a Teoria Crítica Racial no Brasil. In: Denise Auad, Bruno Batista. (Org.). Direitos Humanos, Democracia e Justiça Social. 1ed.São Paulo: Letras Jurídicas, 2017, v. 1, p. 167-204.

CRENSHAW, Kimberlé. Mapping the Margins: Intersectionality, Identity Politics, and Violence against Women of Color. Stanford Law Review, vol. 43, n. 6, p. 1241-1299, jul. 2010.

CRENSHAW, Kimberlé. Documento para o encontro de especialistas em aspectos da discriminação racial relativos ao gênero. Estudos Feministas, vol. 10, núm. 1, p. 171-188, jan. 2002.

CRENSHAW, Kimberlé Crenshaw. From Private Violence to Mass Incarceration: Thinking Intersectionally About Women, Race, and Social Control. 59 UCLA Law Review, n. 52, tbl.2, p. 1418-1472, 2012.

CRENSHAW, Kimberlé. The urgency of intersectionality. 2016. (18m49s). Disponível em: <https://www.youtube.com/watch?v=akOe5-UsQ2o>. Acesso em: 22 Out de 2018.

CURIEL, Ochy. De las identidades a la imbricación de las opresiones: desde la experiencia. In: FLAUZINA, Ana; PIRES, Thula (Org.). Encrespando - Anais do I Seminário Internacional: Refletindo a Década Internacional dos Afrodescendentes (ONU, 2015-2024). Brasília: Brado Negro, 2016.

CURIEL, Ochy. "Género, raza, sexualidad: debates contemporáneos". Colombia: Universidad del Rosario. Disponível em <https://bit.ly/2OJmW4T>. 2014.

CURIEL, Ochy. Los aportes de las afrodescendientes la teoría y la práctica feminista. Desuniversalizando el sujeto "Mujeres", en: Perfiles del Feminismo Iberoamericano, vol.III, Buenos Aires, Catálogos, 2007.

DAVIS Angela; GINA, Dent. A prisão como fronteira: uma conversa sobre gênero, globalização e punição. Santa Catarina, Florianópolis. Revista de Estudos Feministas, EdUFSC, v. 11, n. 2, Jul/Dez, 2003a.

DAVIS, Angela. Are Prisons Obsolete? Estados Unidos da América. New York: Open Media book, 2003b.

DAVIS, Angela. Feminism and Abolition: Theories and Practices for the 21st Century. 2013 (65m30s). Disponível em: 
$\langle$ https://www.youtube.com/watch?v=IKb99K3AEa $>$. Acesso em: 11 Nov de 2018.

DAVIS, Angela. Mulheres, raça e classe. São Paulo: Boitempo, 2016.

DAVIS, Angela. Violence Against Women and the Ongoing challenge to Racism. Kitchen Table, Women of Color Press. 1985

EL PAÍS. Morte de mulheres negras dispara com falta de amparo na periferia. Disponível em: $<$ https://brasil.elpais.com/brasil/2015/11/06/politica/1446816654_549295.h $\underline{\mathrm{tml}>}$, 2015. Acesso em: 11 nov. 2018

ESPINOSA-MIÑOSO, Yuderkys. Una crítica descolonial a la epistemología feminista crítica. El Cotidiano, núm. 184, pp. 7-12, marzoabril, 2014.

FERRARO, Kathleen. The dance of dependency: A geneology of domestic violence discourse, Hypathia, 1996.

FLAUZINA, Ana Luiza Pinheiro. Lei Maria da Penha: entre os anseios da resistência e as posturas da militância. In: FLAUZINA, Ana; FREITAS, Felipe; VIEIRA, Hector; PIRES, Thula. Discursos negros: legislação penal, política criminal e racismo. Brasília: Brado Negro, 2015. p. 115-144.

FLAUZINA, Ana Luiza Pinheiro. A medida da dor: politizando o sofrimento negro. In: FLAUZINA, Ana L. P.; PIRES, Thula, R. O. (Org.). Encrespando - Anais do I Seminário Internacional: refletindo a década Internacional dos Afrodescendentes (ONU, 2015-2024). Brasília: Brado Negro, 2016a.

FLAUZINA, Ana Luiza Pinheiro. O feminicídio e os embates das trincheiras feministas. Discursos Sediciosos, n. 23/24, 2016 b.

FLAUZINA, Ana Luiza Pinheiro. Corpo negro caído no chão: sistema penal e o projeto genocida do estado brasileiro. Dissertação (Mestrado) Pós-Graduação em Direito, Universidade de Brasília, Brasília, 2006.

FRANTZ, Fanon. Pele negra, máscaras brancas. Trad. Renato da Silveira. Salvador: EDUFBA, 2008.

FREITAS. Felipe da Silva. Novas perguntas para a criminologia brasileira: poder, racismo e direito no centro da roda. Cadernos do CEAS. Salvador, n. 238, p. 488-499, 2016. 
GALEANO, Eduardo. As veias abertas da América Latina. Tradução de Galeno de Freitas. 39 a ed. Rio de Janeiro: Paz e Terra, 2000.

GONZALEZ, Lélia. A categoria político-cultural de amefricanidade. Tempo Brasileiro, Rio de Janeiro, no 92/93, p. 69-82, jan./jun. 1988a.

GONZALEZ, Lélia. Por um feminismo afrolatinoamericano. Revista Isis Internacional, Santiago, v. 9, p. 133-141, 1988 b.

GONZALEZ, Lélia. Racismo e sexismo na cultura brasileira. São Paulo, ANPOCS, Ciências Sociais Hoje, 2. ANPOCS, 1983, p. 223-244.

HARAWAY, Donna. Saberes localizados: a questão da ciência para o feminismo e o privilégio da perspectiva parcial. Cadernos Pagu, Campinas, n. 5, p. 7-41, jan. 2009.

HARRIS, Angela P. Race and Essentialism in Feminist Legal Theory. Stanford law Review, v. 42, n. 3, p. 581-616. Disponível em <https://bit.ly/2DeTPDr $>$. 1990.

hooks, bell. Ain't I a Woman: Black Women and Feminism. London: Pluto Press, 1982.

IPEA - Violência Contra a Mulher e as práticas institucionais. Brasília: IPEA, 2015 [Série pensando o Direito $\mathrm{n}^{\mathrm{o}}$ 52]. Disponível em $\langle$ https://bit.ly/2A21a6a $>$

LORDE, Audre. The Master's Tools Will Never Dismantle the Master's House. Disponível em <https://bit.ly/2S59PfF>, 1979

LUGONES, María. Rumo a um feminismo descolonial. Estudos Feministas, Florianópolis, v. 22, n. 3, p. 935-952, 2014

LUGONES, Maria. Decoloniality of Gender. Disponível em <https://bit.ly/2PTREMl>. 2008.

MEDEIROS, C. S. L. Q. ; MELLO, M. M. P. . Não à retratação? O lugar da intervenção penal no crime de violência doméstica contra a mulher. Revista Brasileira de Sociologia do Direito, v. 1, p. 47-62. 2014 a.

MEDEIROS, C. S. L. Q. ; MELLO, M. M. P. O que vale a pena? O impacto da Lei Maria da Penha no encarceramento de agressores e seus efeitos colaterais sobre a mulher vítima de violência doméstica e familiar. In: CONPEDI; UFPB. (Org.). Criminologias e Política Criminal I: XXIII Congresso Nacional do CONPEDI. 1ed. João Pessoa: CONPEDI, v. 1, p. 447-469. 2014b. 
MEDEIROS, C. S. L. Q. ; MELLO, M. M. P. . O simbolismo da Lei Maria da Penha no enfrentamento da violência doméstica e familiar contra a mulher. In: João Paulo Allain Teixeira; Louise Dantas de Andrade. (Org.). Jurisdição, Processo e Direitos Humanos. 1ed.Recife: APPODI, v. 1, p. 1827. 2014c.

MENDES, Soraia da Rosa. Criminologia feminista: novos paradigmas. São Paulo: Saraiva, 2014.

MENDOZA, Breny. La epistemologia del sur, la colonialidad del género y el feminismo latinoamericano. In: MINOSO, Yuderkys Espinosa (Coord.). Aproximaciones críticas a las prácticas teórico-políticas del feminismo latinoamericano. Buenos Aires: En la frontera, 2010.

MIGNOLO, Walter. La idea de América Latina (la derecha, la izquierda y la opción decolonial). Crítica y Emancipación, (2): p. 251-276, primer semestre 2009.

MONJE, Fabiana. Las limitaciones teóricas respecto a la violencia de género contra las mujeres: aporte desde el feminismo descolonial para el análisis en mujeres de América Latina. Iberoamérica Social: revista-red de estudios sociales VII, pp. 129 - 153, 2017.

MORAES, Orlinda C. R. de; MANSO, Flávia V. Dossiê Mulher 2018. Rio de Janeiro: Rio Segurança. Instituto de Segurança Pública (ISP - RJ), 2018

OLIVEIRA, Adriana Vidal de; COSTA, Rodrigo de Souza. Lei 11.340/04 e Sistema Penal: a utilização do Direito Penal pelos Juizados de Violência Doméstica e Familiar Contra a mulher. Disponível em: $<$ http://publicadireito.com.br/artigos/?cod=45b430710ad04765> Acesso em 19 Nov 2018.

OYĚWÙMÍ, Oyèrónké. Conceituando o gênero: os fundamentos eurocêntricos dos conceitos feministas e o desafio das epistemologias africanas. Tradução para uso didático de: OYĚWÙMí, Oyèrónké. Conceptualizing Gender: The Eurocentric Foundations of Feminist Concepts and the challenge of African Epistemologies. African Gender Scholarship: Concepts, Methodologies and Paradigms. CODESRIA Gender Series. Volume 1, Dakar, CODESRIA, 2004, p. 1-8

PAIXÃO, Marcelo. A lenda da modernidade encantada: por uma crítica ao pensamento social brasileiro sobre relações raciais e projeto de Estado Nação. Rio de Janeiro: CRV, 2014. 
PEIXOTO, Maria Gabriela Viana. Vítimas e controle punitivo: Um percurso pelos discursos acadêmicos no Brasil Contemporâneo. 1 ed. Rio de Janeiro: Lumen Juris, 2016

PEREIRA, Bruna Cristina Jaquetto. Tramas e dramas de gênero e de cor: a violência doméstica e familiar contra mulheres negras. Brasília: Brado Negro, 2016.

PIRES, Thula; GIL, Andréa "Chega de conversa mole, o papo agora é reto!". Empório do Direito. Disponível em $<$ https://bit.ly/2ODXpZZ $>$, 2017.

PIRES, Thula; GIL, Andréa. "O que a normalização do estupro tem a informar sobre a sociedade brasileira?" Disponível em <https://bit.ly/2Fhl1UP>, 2017

PIRES, Thula. Criminologia crítica e pacto narcísico: por uma crítica criminológica apreensível em pretuguês. Revista Brasileira de Ciências Criminais. vol. 135. ano 25. p 541-562. São Paulo: Ed. RT, set. 2017

PIRES, Thula. "Não solte a minha mão, que eu não soltarei a de vocês". Empório do Direito. Disponível em <https://bit.ly/2z6T7W3>, 2018

PIEDADE, Vilma. Dororidade. São Paulo: Editora Nós, 2017

PRANDO. Camila Cardoso de Mello. O que veem as mulheres quando o Direito as olha? Reflexões sobre as possibilidades e os alcances de intervenção do Direito nos casos de violência doméstica. Disponível em: <https://bit.ly/2qH2Y05>, 2016.

QUIJANO, Aníbal, "Colonialidade do poder, globalização e democracia", Novos Rumos, ano 17, n. 37, 2002.

QUIJANO, Aníbal. Colonialidade do poder, eurocentrismo e América Latina. In: LANDER, Edgardo (Org.). A colonialidade do saber: eurocentrismo e ciências sociais. Buenos Aires: Conselho Latino-americano de Ciências Sociais - CLACSO, 2005.

RAMOS, Guerreiro. "Patologia social do branco brasileiro". Jornal do Comércio, jan. 1955

RESENDE, Amanda. Opressão de gênero: a ausência de um olhar interseccional na busca de soluções jurídicas. Orientadora: Thula Pires. Monografia (Graduação) - Graduação em Direito, Pontifícia Universidade Católica do Rio de Janeiro, Rio de Janeiro, 2017. 
RICHIE, Beth E. A Black Feminist Reflection on the Antiviolence Movement. In: SOKOLOFF, N. J; PRATT, C. (Org.) Domestic Violence at the Margins: Reading on Race, Class, Gender, and Culture. New Jersey: Rutgers University Press, 2010. p. 50-55.

RICHIE, Beth E. Arrested Justice: Black Women, Violence, and America's Prison Nation. New York University Press, 2012.

SANTOS, Carla Adriana da Silva. Opái Prezadas! Racismo e Sexismo Institucionais tomando bonde no Conjunto Penal Feminino de Salvador. Dissertação (Mestrado). Mestrado em Estudos Interdisciplinares Sobre Mulheres, Gênero e Feminismo. Universidade Federal da Bahia, Bahia, 2012.

SILVEIRA CAMPOS, Marcelo da. Crime e Congresso Nacional no Brasil pós-1988: uma análise da política criminal aprovada de 1989 a 2006. Dissertação (mestrado). Universidade Estadual de Campinas, 2010.

SPIVAK, Gayatri Chakravorty. Pode o subalterno falar? Trad. Sandra Goulart Almeida, Marcos Pereira Feitosa e André Pereira Feitosa. Belo Horizonte: Editora UFMG, 2010.

VARGAS, João Costa. A Diáspora Negra como Genocídio. 1 Revista da ABPN, v. 1. n. 2, Jul-Out. 2010.

WAISELFISZ, J. J. Mapa da violência 2015. Homicídios de Mulheres no Brasil. Brasília, 2015. Disponível em <https://www.mapadaviolencia.org.br/pdf2015/MapaViolencia_2015_mulh eres.pdf $>$

WERNECK, Jurema. A era da inocência já acabou, já foi tarde. In: AshokaEmpreendedores Sociais; Takano. (Org.). Racismos Contemporâneos. 1ed.Rio de Janeiro: Takano Editora, 2003.

WERNECK, Jurema. De Ialodês e Feministas: Reflexões sobre a ação política das mulheres negras na América Latina e Caribe. Nouvelles Questions Féministes - Revue Internationale Francophone, vol. 24, n. 2, 2005.

WERNECK, Jurema; MENDONÇA, Maísa; WHITE, Evelyn C. O livro da saúde das mulheres negras: nossos passos vêm de longe. 2 ed. Rio de Janeiro: Pallas/Criola, 2006. 
